NIST Technical Note 2120

\title{
Gas vs Electric: Sustainability Performance of Heating Fuel Options in the NIST NZERTF
}

David Webb

Joshua Kneifel

This publication is available free of charge from:

https://doi.org/10.6028/NIST.TN.2120

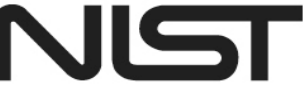

National Institute of Standards and Technology U.S. Department of Commerce 
NIST Technical Note 2120

\section{Gas vs Electric: Sustainability Performance of Heating Fuel Options in the NIST NZERTF}

David Webb

Joshua Kneifel

Office of Applied Economics

Engineering Laboratory

This publication is available free of charge from:

https://doi.org/10.6028/NIST.TN.2120

September 2020

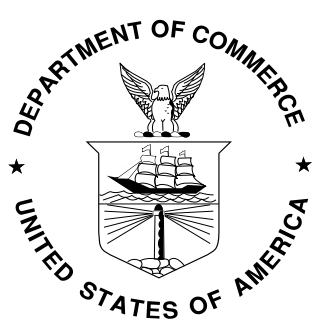

U.S. Department of Commerce Wilbur L. Ross, Jr., Secretary 
Certain commercial entities, equipment, or materials may be identified in this document in order to describe an experimental procedure or concept adequately. Such identification is not intended to imply recommendation or endorsement by the National Institute of Standards and Technology, nor is it intended to imply that the entities, materials, or equipment are necessarily the best available for the purpose.

National Institute of Standards and Technology Technical Note 2120 Natl. Inst. Stand. Technol. Tech. Note 2120, 40 pages (September 2020) CODEN: NTNOEF

This publication is available free of charge from: https://doi.org/10.6028/NIST.TN.2120 


\title{
Preface
}

This manuscript builds on analysis completed in an article by O'Rear, Webb, Kneifel and O'Fallon (1) that focuses on a case study evaluating the sustainability performance of singlefamily homes in Maryland. Since most of the background, literature, methodology, and analysis remain the same, numerous sections are abbreviated versions of sections in the article For additional details on these sections refer to the prior study.

\begin{abstract}
Updates to the underlying cost and environmental data have recently been implemented in the BIRDS database. This study evaluates the updated results for validation, as well as determines the potential changes in the results relative to those found in O'Rear, Webb, Kneifel and O'Fallon (1). The updates are found to have a minor impact on the total LCC and the LCA results, but there is a shift in some energy efficiency measures (EEMs) in optimal designs. The continued reduction in solar photovoltaic (PV) installation costs leads to larger system sizes being utilized in life-cycle cost (LCC) designs, while including few additional EEMs. Reducing the efficiency of some building components is possible and still reaching net-zero energy performance. As in the previous study, net-zero energy performance is reached at the lowest LCC using an all-electric design. The incremental increase in initial construction costs relative to the code-compliant design in Maryland is \$28 222, which has continued a trend in decreasing premium for net-zero energy performance. Over the 30-year study period, NZLCC-E saves the homeowner \$34 063. Although the homeowner could save more designing to meet the lowest LCC design using natural gas heating (LCC-NG), the additional savings is only $\$ 527$ while still consuming about $50 \%$ of the baseline building design's total energy.

The concept of low-energy buildings must be reconsidered to determine whether new targets should be set, such as a combination of total consumption and net consumption or net-zero goals that include embodied energy. These results are limited in their generalization because they are based on a case study using validated simulation models of the NIST Net-Zero Energy Residential Test Facility (NZERTF). The findings should not be extrapolated to buildings with different climates, energy costs, building codes, or occupancies. The assumptions on the economic analysis are also important factors to consider when using the results and implications in this study for decision making. The baseline building designs in this study are based on 2015 IECC. Maryland has since adopted 2018 IECC, which would influence the relative differences between the optimal designs and the baseline.
\end{abstract}

\section{Key words}

Space heating; domestic water heating; low-energy; net-zero energy: life-cycle assessment; life-cycle costing. 


\section{Table of Contents}

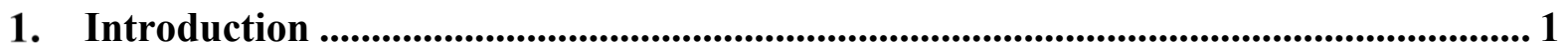

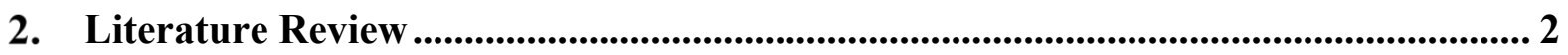

2.1. Gas vs. Electric Space Heating Components ………………………....................... 2

2.2. Water Heating Comparison ........................................................................... 3

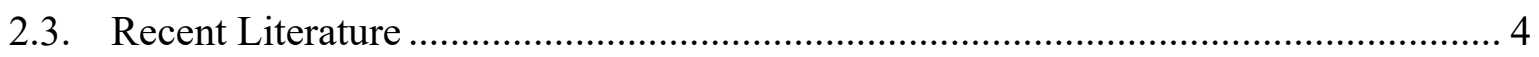

3. Measuring Building Sustainability Using BIRDS ............................................................... 4

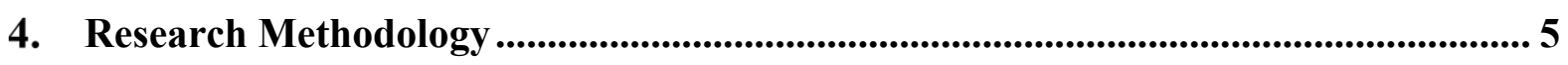

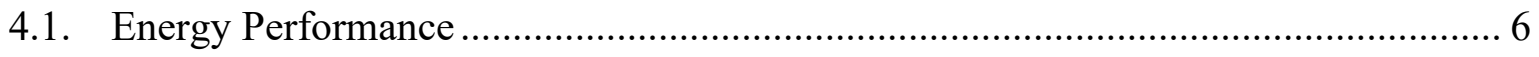

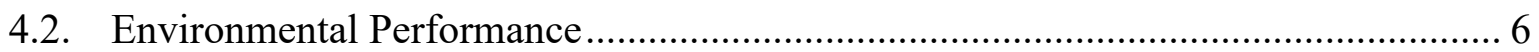

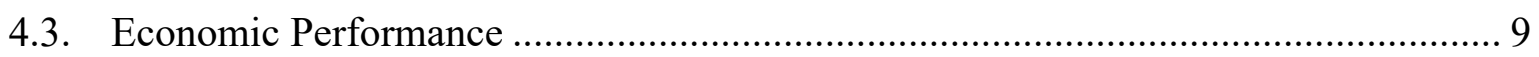

4.4. Building Component Options and Analysis Assumptions ....................................... 10

5. Results and Discussion ...................................................................................................... 11

5.1. Comparison of Maryland Code Compliant Designs ................................................ 11

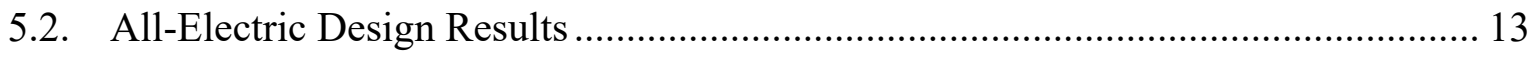

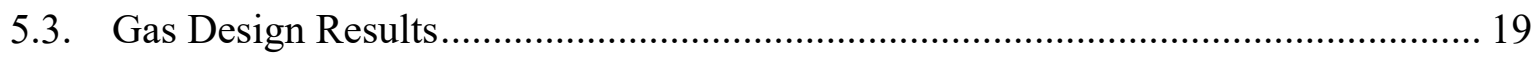

5.4. Cross-comparisons of selected building designs ................................................... 23

6. Conclusion, Implications and Future Research................................................................ 26

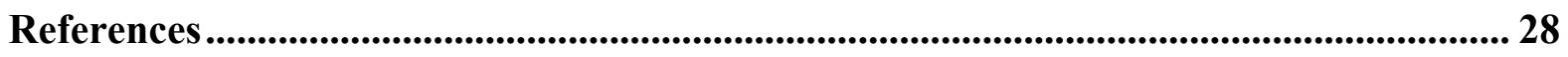

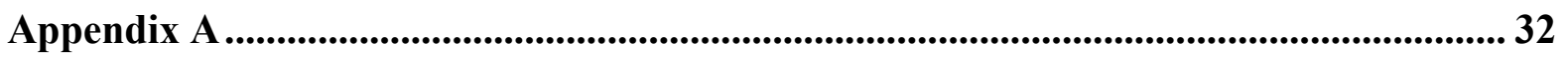

\section{List of Tables}

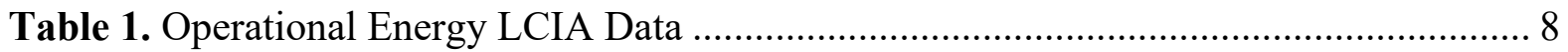

Table 2. Operational Energy Impact Ratios by Data Source ………………………….......... 9

Table 3. Maryland Code-Compliant Home Design Specifications......................................... 10

Table 4. HVAC and DHW Specifications for Alternative Baseline Designs ........................ 11

Table 5. Results for Maryland Code Compliant designs from [1] ....................................... 11

Table 6. Results for Maryland Code Compliant Designs using Updated Data...................... 12

Table 7. Design Features for All-Electric and Gas-heated EE and LCC Building Designs

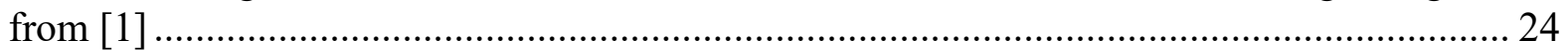

Table 8. Design Features for All-Electric and Gas-heated EE and LCC Building Designs

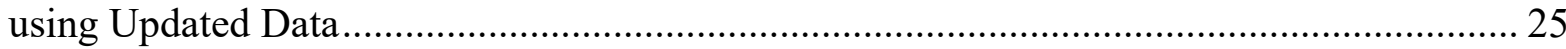

Table 9. Environmental Impact Score (EIS) by Key Design and Weighting Approach........ 25

Table A-1. Constructions - Roof, Ceiling, Wall and Foundation 32

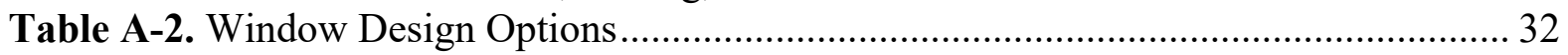

Table A-3. Design Options for Alternative Air Leakage Rates ............................................ 33

Table A-4. Fraction of High Efficiency Fixtures by Requirement ........................................ 33

Table A-5. Heating and Cooling Equipment Design Options............................................... 33 
Table A-6. Domestic Hot Water System Design Options.............................................. 33

Table A-7. Solar PV System Options ............................................................................. 33

Table A-8. Normalization References (Annual U.S. Contributions) and EIS Weights ......... 34

\section{List of Figures}

Figure 1. NERC Regions and Balancing Authorities ................................................... 7

Figure 2. Basins that Account for Majority of U.S. Natural Gas Production [53] ................ 8

Figure 3. MCC-E vs. MCC-NG Designs (fractional performance relative to MCC-E

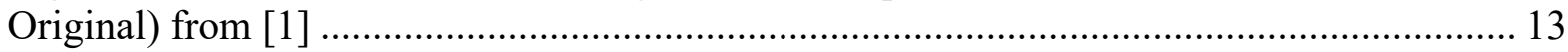

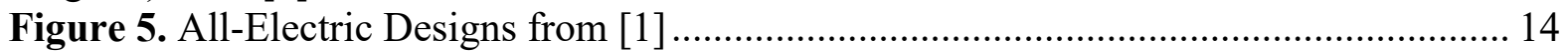

Figure 6. All-Electric Designs using Updated Data..................................................... 15

Figure 7. Optimization Curves for All-Electric Designs based on (a) HVAC System and (b)

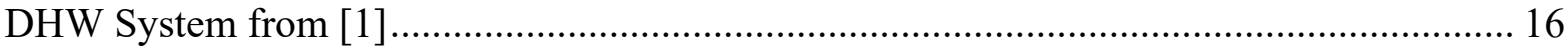

Figure 8. Optimization Curves for All-Electric Designs based on (a) HVAC System and (b)

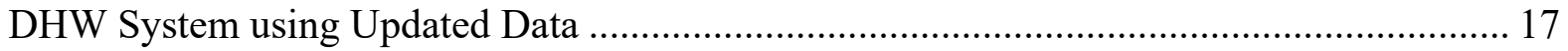

Figure 9. All-Electric Designs based on Solar PV System Capacities from [1] .................. 18

Figure 10. All-Electric Designs based on Solar PV System Capacities using Updated Data 18 Figure 11. Gas-heated Designs based on Fractional Reduction in (a) Total Energy Use and (b) Electricity Use from [1] .................................................................................... 19

Figure 12. Gas-heated Designs based on Fractional Reduction in (a) Total Energy Use and (b) Electricity Use using Updated Data ...................................................................... 20 Figure 13. Optimization Curves for Gas-heated Designs based on (a) HVAC System and (b) DHW System from [1]

Figure 14. Optimization Curves for Gas-heated Designs based on (a) HVAC System and (b) DHW System using Updated Data 


\section{Introduction}

A focus on sustainable infrastructure in the U.S. has given rise to interest in cost-effective low-energy residential buildings, even goals of reaching net-zero (or net-zero ready) energy performance. The feasibility of reaching net zero energy performance and the optimal building design is impacted by the selected definition of net-zero (e.g., site energy versus source energy) as well as the climate of the building being constructed. There is limited research on the impact of heating fuel type selection on sustainability performance when evaluating low-energy buildings. Space and water heating accounts for a significant fraction of home energy consumption $(\approx 40 \%)$, and consumers often have an option between natural gas and electric heating systems.

Although fuel and equipment costs, climate/region, and home age are the primary influencers in the selection process, other factors such as maintenance costs, safety concerns, and personal preferences may also impact heating equipment choice. Natural gas is currently cheaper than electricity per unit of energy and typically has lower source emissions rates relative to electricity from the power grid. However, natural gas equipment requires a local distribution system connection, have lower efficiencies, and result in some risk to exposure of leaked gas and exhaust.

Gas heating has been recommended for colder climates with more extreme heating loads, while electric heating is recommended in warmer climates where fuel cost savings are minimal due to the low heating loads. Natural gas is the most widely used fuel type and class of heating technology in the U.S. followed by electricity [2]. The majority heating source varies by region, with the warmest climate (Hot-Humid) being primarily electricity. The fraction of electric heating decreases and the fraction of natural gas heating increases as the climate gets colder with approximately equal shares in the Mixed-Humid climate zone and all other climate zones being dominated by natural gas. [3, 4].

Previous work in O'Rear, Webb, Kneifel and O'Fallon (1) compared a set of gas heating systems against electric heating systems in the context of low and net-zero homes using the Building Industry Reporting and Design for Sustainability (BIRDS) database. Since the prior study, the data underlying BIRDS has been updated to include new cost and environmental data $^{1}$. Dollar values have been inflated from 2015 to 2018 dollars while construction costs have been updated with more recent consumer price indices and industry construction costs, specifically for solar photovoltaic systems. The environmental data for operational energy consumption has also been updated to incorporate electricity and natural gas life cycle assessment (LCA) data published since the analysis in the previous study. The purpose of this report is to implement the exact same methodology to reanalyze the same whole building sustainability metrics for the gas versus electric comparisons with the more recent underlying data to understand what, if any, results and associated interpretations from the previous work have changed.

\footnotetext{
${ }^{1}$ Update occurred in September 2020
} 


\section{Literature Review}

As in the previous study, three types of space and water heating equipment are considered in this study: gas furnace, electric resistance furnace, and electric heat pump for space heating, and gas fired water heater, electric resistance water heater, and heat pump water heater for water heating. The literature on space and water heating in residential buildings is discussed below. Solar thermal as a supplemental heat source for domestic hot water is included in the BIRDS database but is excluded from the analysis. The reason for which is presented below.

\subsection{Gas vs. Electric Space Heating Components}

The literature on direct comparisons of the economic and environmental efficiency of gas and electric heating is limited. Additionally, studies are often limited in generalization because of the significant economic and environmental differences in underlying conditions across locations, including the cost, fuel mix, and efficiency of electricity generation. For example, the sustainability performance of a building consuming electricity from a coal-fired generating facility will be different than that same building consuming electricity from a mixture of utility-scale solar PV, wind farms, and natural gas-fired generation. As such, all operational energy-related analysis is implicitly based on the fuel mix of the region in each study. The remainder of Section 2.1 and all of Section 2.2 are abbreviated versions of the literature review in O'Rear, Webb, Kneifel and O'Fallon (1).

Several studies have found natural gas to be cost-effective relative to electricity for heating in the United States. Belsie (5) found that natural gas was $28 \%$ cheaper than electricity for heating in the Northeast region. EIA (6) reports that the U.S. average winter expenditure per household for natural gas used for heating $(\$ 578)$ is $38 \%$ less than for electricity (\$930).

Most studies comparing electric and gas heating equipment were completed for non-U.S. locations. Jeong, Kim and Lee (7) found natural gas has a higher utility (defined as a function of equipment cost, energy costs, and energy consumption given a budget constraint) when compared with electricity generation in South Korea. Gustavsson and Karlsson (8) found that electrical heating systems could be either the most energy-efficient option or the least, depending on the selected system. Several studies from the U.K. and European Union have generally found that air-source heat pumps are better than gas heating in terms of direct greenhouse gas emissions [9-11], but more costly to operate than gas heating [10]. Dorer and Weber (11) focused on micro-cogeneration, which is different than the focus of this paper, while Kelly and Cockroft (10) and Cabrol and Rowley (9) looked at gas condensing boilers, which are typically more efficient than forced air (non-condensing) furnaces but uncommon in U.S. single-family homes. Yang, Zmeureanu and Rivard (12) found similar results in comparing electric and gas fired hot water systems and forced air furnaces for space heating in Quebec.

Evaluating gas and electric heating equipment in the U.S. is more complicated due to variation in generation fuel mix across the country. Shah, Debella and Ries (13) found that heat pumps have higher environmental impacts in places where there is a high percentage of fuel generation from fossil fuels, with a transition of $15 \%$ to $40 \%$ of fossil fuel generation to renewable sources required to offset these impacts. Brenn, Soltic and Bach (14) performed a comparison of electric and natural gas driven heat pumps in Central Europe that found, in general, natural gas heat pumps were roughly equivalent to electric heat pumps using 
electricity from natural gas combined cycle generators. Alternatively, if the electrical grid utilized low- $\mathrm{CO}_{2}$ fuel sources, an electric heat pump is preferred. Pitt, Randolph, Jean and Chang (15) found that heating with a gas furnace had lower $\mathrm{CO}_{2}$ emissions than using airsource heat pumps in Blackburn, VA. The difference in findings is due to Europe using far more nuclear (25\%) and renewables (30\%) than the U.S. (18\% nuclear and $21 \%$ renewables), with the U.S. relying substantially more on coal in 2016 [16]. Europe sees similar variation in optimal technology both across countries [17] and within countries [18, 19].

\subsection{Water Heating Comparison}

There is little direct comparison of water heating technologies in the literature for the U.S. However, there have been multiple studies on energy and environmental performance conducted in Europe. Tsilingiridis, Martinopoulos and Kyriakis (20) compared the lifetime environmental impact of a gas, electric, passive solar, and two types of hybrid passive solar water heaters (one using electricity and one using natural gas). A net gain in environmental performance was found for the hybrid systems compared to an electric water heater, with the hybrid-electric system outperforming the hybrid-gas system. Tsilingiridis, Martinopoulos and Kyriakis (20) also found that the natural gas water heater performed the best, outperforming the hybrid-electric system due to the lower efficiency of the electrical component of the hybrid system. Hong and Howarth (21) found that natural gas water heaters led to higher direct greenhouse gas emissions than high efficiency electric heat pump water heaters for both coal and natural gas produced electricity. Their findings suggest that natural gas technologies can result in higher emissions than using coal-fired electricity generation if efficiency gains in coal burning can more than offset the higher per unit of energy emissions rates for coal relative to natural gas.

A study of multiple environmental impacts that focused on solar thermal water heating versus heat pumps and gas boilers found tradeoffs for each technology type. Greening and Azapagic (22) found that solar thermal systems are not necessarily the "cleanest" option in terms of overall environmental impact. Solar thermal outperformed electric resistance water heaters and electric heat pump water heaters but underperformed gas boilers in a majority of environmental categories.

Economic comparisons between technologies in the literature are also limited, with most studies being completed by trade groups. Gas water heaters tend to cost less to operate on average than electric water heaters and are generally less efficient on a site energy basis. Although solar thermal water heaters can help reduce greenhouse gas emissions, the bulk of literature suggests that they are not economical for the United States. A report by Clark (23) found that solar thermal had a payback period for installation costs of roughly 30 years. Croxford and Scott (24) suggests a short carbon payback time (no longer than $20 \%$ of system lifetime), but a simple payback of 100s of years for solar thermal if grants or rebates are included. The National Renewable Energy Laboratory (NREL) found that break-even costs were obtainable for solar thermal water heating systems using electric back-up based high solar resource availability, low electricity prices and high natural gas prices [25]. Solar thermal was also found to be more likely to replace some conventional electric systems as opposed to natural gas systems. Rockenbaugh, et al. (26) had similar findings where proper siting and careful consideration can make solar thermal economically efficient in certain locations in the United States. If conventional heating sources are used to supplement solar 
thermal, then a hybrid system can outperform traditional water heaters even in suboptimal climates [27].

Studies in the European Union have found that solar thermal can be economically and environmentally competitive in the appropriate climate and with sufficient solar resources [28-30]. Simons and Firth (31) found that solar thermal in apartment buildings in Europe outperformed other heating sources on primary energy purchased and reductions in emissions, however, these benefits are a trade-off for more substantial negative environmental impacts due to the embodied emissions from the equipment manufacturing process. Solar thermal systems were found to be better overall for human health than fossil fuel systems and similar to heat pump systems. Kalogirou (32) found that a solar thermal system coupled with a gas or electric backup proved viable in reducing greenhouse gas emissions with a realistic payback period. A cost-benefit analysis of solar thermal water heating in Greece concluded that solar water heating was cost-effective relative to electric water heaters, but was not cost-effective relative to natural gas [33]. Subsequent work by Martinopoulos, Papakostas and Papadopoulos (17) has shown that advancements in solar thermal have led it to now be more cost-effective than natural gas water heating in Greece.

The data used in this paper, further discussed in Section 3, uses a fuel mix and technologies (appropriate for the selected location) that lead to a solar thermal system being non-optimal in all cases based on the chosen energy and economic efficiency metrics, and is therefore excluded from the discussion within the current analysis.

\section{3. $\quad$ Recent Literature}

Literature has been published comparing gas and electric heating since O'Rear, Webb, Kneifel and O'Fallon (1). Eguiarte, Garrido-Marijuán, de Agustín-Camacho, del Portillo and Romero-Amorrortu (34) found that heat pumps become more cost-effective as total energy consumption increases, but natural gas water heating remains the most efficient equipment option. Zhao, et al. (35) examined the impacts on emissions in moving from coal-fired to other energy sources in China and found that pollution decreased significantly in switching to natural gas or other non-coal based electricity sources. Another study in China found that natural gas was insufficient to fully decarbonize the heating sector, requiring heat pumps to reach that goal [36].

\section{Measuring Building Sustainability Using BIRDS}

BIRDS provides whole-building sustainability metrics developed using whole-building energy simulation modeling, life-cycle costing, and life-cycle impact assessment (LCIA) methods to produce science-based measures for evaluating high-performance green buildings [37]. BIRDS environmental performance metrics are based on a hybridized LCA approach, which considers an inventory of inputs and outputs covering all phases of a building's service life. Operational energy consumption in the building includes any on-site renewable energy generation [37]. Environmental LCIA quantifies the potential contribution of these LCA inventories to a range of environmental impact categories based on EPA's TRACI 2 impact categories [38] plus two additional impact categories for land and water use. The remainder of this chapter is an abbreviated version of the same section in O'Rear, Webb, Kneifel and O'Fallon (1). 
The latest version of BIRDS (v4.1) is scheduled to be released in 2020 and includes an update to one of the three databases in BIRDS, the "Incremental Energy Efficiency for Residential Buildings Database" that includes updates to the underlying cost data and operational energy LCA data. The analysis conducted in this study is based on this updated database (referred to as the BIRDS Database hereafter), which allows for detailed analyses of incremental EEMs for Gaithersburg, MD based on NIST's Net Zero Energy Residential Test Facility (NZERTF). BIRDS users can evaluate impacts of alternative underlying assumptions, including study period (1 to 30 years), discount rate (3\% or $8 \%)$, construction quality (average or luxury), financing type (20\% down loan or paid in full upfront), exterior wall finish (brick veneer or wood siding), and heating fuel type (electricity or natural gas).

Appendix A provides the EEM options available in the BIRDS Database. Table A-1 and Table A-3 in the Appendix list alternative EEM options for building envelope constructions (i.e., wall, roof/ceiling, foundation, windows, doors, air leakage rates), which are based on requirements in different editions of IECC for Residential Buildings and components installed in the NZERTF ${ }^{23}$. Listed in Table A-4 through Table A-7 are the EEM options for building systems (lighting, space conditioning, water heating, solar photovoltaics (PV)). Lighting wattage options (Table A-4) are on a "typical/baseline" lighting mix from Hendron and Engebrecht [39], requirements in different editions of IECC, and the NZERTF. ${ }^{4}$

Heating and cooling equipment options (Table A-5) include both electric and gas space heating system. For each fuel type there are two equipment options: a "standard efficiency" system that satisfies minimum federal efficiency and IECC requirements and a "high" efficiency system based on what was deemed a cost-effective high-end system based on the NZERTF design. Mechanical dedicated outdoor air (OA) ventilation requirements defined in ASHRAE 62.2-2010 [40] are met for all systems. The high efficiency systems include a heat recovery ventilator $(\mathrm{HRV})$.

Eight DHW system options are available (Table A-6), which are different combinations of a "standard" efficiency electric water heater, an air-to-water heat pump water heater (HPWH), a standard efficiency gas water heater, or a high efficiency gas water heater with and without an auxiliary two-panel solar thermal system.

The six roof-mounted solar photovoltaic (PV) system options (Table A-7) are incremental sizes ranging from $25 \%$ to $125 \%$ of the NIST NZERTF roof-mounted system (Option 5).

\section{Research Methodology}

This study explores tradeoffs in sustainability (energy, environmental, and economic) performance between residential building designs that use electric space and water heating equipment and natural gas-fired equipment. This chapter provides the methodology applied in this study and is an abbreviated version of the Research Methodology in O'Rear, Webb, Kneifel and O'Fallon (1).

\footnotetext{
${ }^{2}$ The 2003 and 2006 IECC set no maximum limit on air leakage. The 2009 IECC limit is assumed for those editions in this study.

${ }^{3}$ Required conversion from air changes per hour to effective leakage area (ELA) done using formula in Chapter 16 of ASHRAE (2012). The ELA is split between the two conditioned floors based on fractional volume.

${ }^{4}$ Additional details on all EEM alternatives can be found in Kneifel, Lavappa et al. (2016).
} 


\subsection{Energy Performance}

Operating energy is based on an estimate of total net source energy use by a building's occupants during the building's service life from parametric simulation runs of EnergyPlus $(\mathrm{E}+)[41,42] .^{5,6}$ Total net site energy use is the difference between total consumption and onsite renewable energy production. Total net source energy use is derived using a conversion multiplier to scale net site operating energy use. ${ }^{7}$

Annual operating energy use is assumed constant from year-to-year with proper maintenance. On-site solar PV production, based on previous research studies, is assumed to have an annual production degradation rate of $0.5 \%$ per year over the lifetime of the solar PV system [44]. The estimates for net operating energy use over a selected study period are also used to derive net operating $\mathrm{CO}_{2}$ emissions over the same study period.

\subsection{Environmental Performance}

Environmental performance uses LCA inventory data and life-cycle impact assessment (LCIA) methods to quantify and link environmental impact contributions to twelve impact categories. ${ }^{8}$ BIRDS uses a hybrid LCIA framework developed by Suh and Lippiatt (45) that integrates top-down (Input-Output-based) and bottom-up (process-based) methods [46-50]. For additional details on the LCA inventory data see Lippiatt, Kneifel, Lavappa, Suh and Greig (37). The environmental flows associated with a building's life-cycle stages can be grouped in embodied flows [initial construction, maintenance, repair, and replacement (MRR), and disposal] and operating flows (energy consumed and produced during building operation). See Kneifel, O'Rear, Webb and O'Fallon (51) for approaches implemented to calculate the embodied and operating environmental flows. ${ }^{9,10}$

The underlying LCIA data is identical to that used in Kneifel, O'Rear, Webb and O'Fallon (51) except for operational electricity and natural gas. Since its publication, new LCA data has been published for each by federal agencies that provides improved methodologies, approaches, and LCI flows as well as more recent underlying source data. These LCI data, summarized below, are publicly available and well documented.

The Federal LCA Commons created a publicly available Electricity Baseline LCA Model (collaborative effort between EPA, USDA, and DOE national laboratories) that can calculate the LCA data (generation-based or consumption-based) for any region (national average,

\footnotetext{
${ }^{5}$ Site energy refers to the amount of energy shown on a utility bill. It is the final form of energy consumed by the homeowner.

${ }^{6}$ The weather file used for the simulations is the Typical Meteorological Year 3 (TMY3) for Gaithersburg, MD (KGAI weather station) obtained from Weather Analytics [43] Weather Analytics (2014) TMY Meteorological Year 3 (TMY) Formatted Weather Data File. ed Database A-GW (Athenium Analytics (formerly Weather Analytics), https://www.athenium.com/).

${ }^{7}$ Source energy refers to the total amount of raw fuel used to power a building and maintain its daily operations. It considers all energy use, including production, transmission, and delivery losses.

${ }^{8}$ The twelve categories can be found in Table A-8. More information on the impact categories, refer to [37] Lippiatt B, Kneifel J, Lavappa P, Suh S, Greig A (2013) Building Industry Reporting and Design for Sustainability (BIRDS) Technical Manual and User Guide. NIST Technical Note 1814.

${ }^{9}$ Building operation includes the energy consumed by the building and associated environmental flows over the study period. The energy use emissions are derived using LCA data based on the emissions rates for electricity and natural gas generation in Maryland, which treats all consumption and production (electricity only) the same temporally.

${ }^{10}$ Natural gas environmental flows are calculated by multiplying the source flow per unit of natural gas by the total net number of units of natural gas consumed each year in the study period and summing across all years. The sum of the flows for electricity and natural gas gives the total operational energy-related flows.
} 
FERC market region, balancing authority) in the country. The electricity baseline was accessed in the Grid Mix Explorer tool to calculate the LCIA for electricity consumed in the PJM balancing authority (shown in the red dashed box of Figure 1) [52].

\section{U.S. electric power regions}

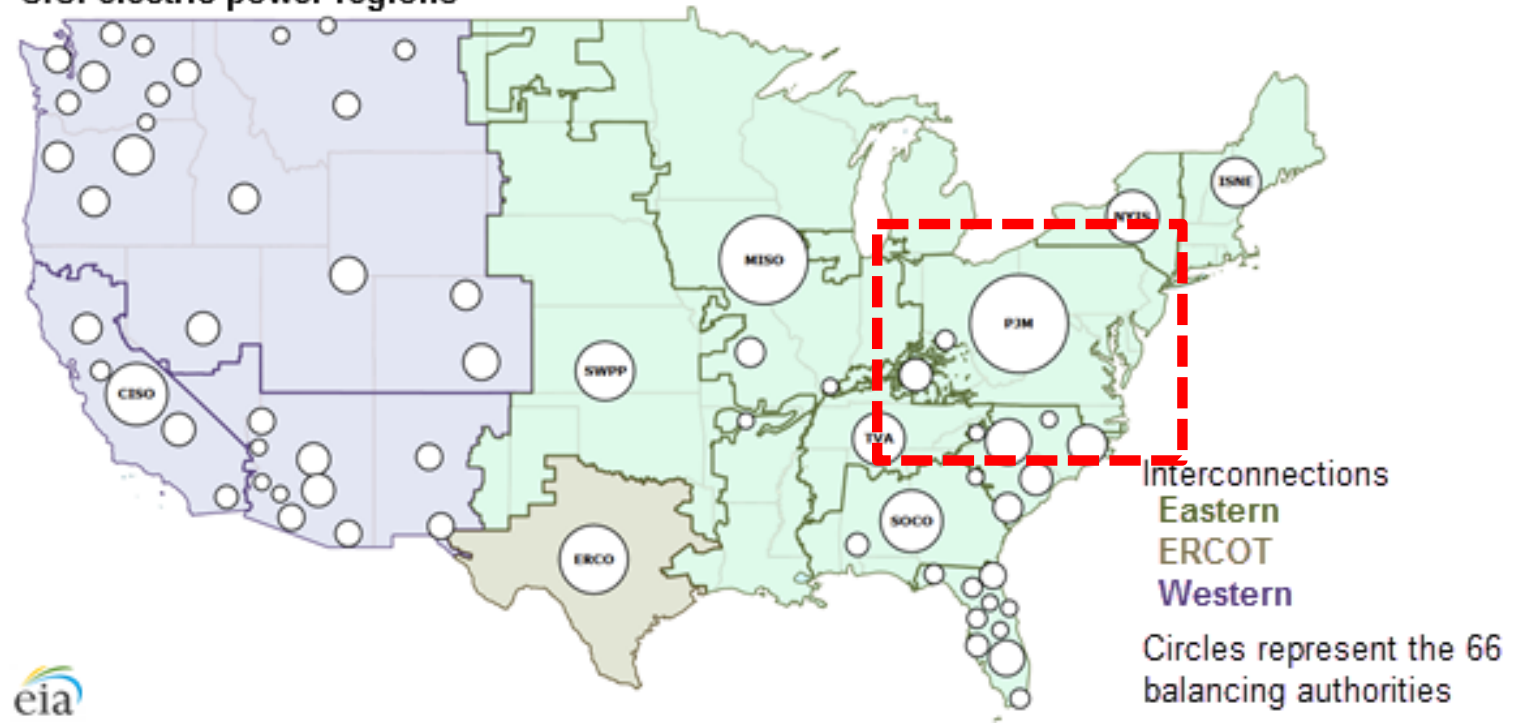

Figure 1. NERC Regions and Balancing Authorities ${ }^{11}$

The electricity baseline was developed using emissions reported to the EPA via three main programs: Air Markets Programs Data, the National Emissions Inventory (NEI), and the Toxics Release Inventory (TRI). The inventory is divided by the annual generation reported to the Energy Information Administration (EIA) (Form 923) for each power plant in the United States. The remainder of the life cycle is completed using data from NETL coal, natural gas, and petroleum baseline models to represent the supply chain emissions associated with extracting and transporting the fuels [53]. These models primarily rely on the same EPA inventories used for power plant stack emissions. Other non-fossil technologies (e.g., wind, solar, nuclear, geothermal, hydro) are largely based on existing models modified in consultation with other DOE experts.

NETL published a Natural Gas Baseline LCA Model that provides both national average as well as basin specific LCA data for the delivery of direct use natural gas (excluding on-site combustion). The two baseline databases published in 2019 (2016 data) were used to generate consumption-based LCIA results for the PJM balancing authority (where Maryland is located) and LCIA results for average delivered (direct use) natural gas produced in the Appalachian Shale basin using it's respective extraction technologies (100\% shale), which can be identified as the eastern-most natural gas basin in the U.S. (see red dashed box in Figure 2).

\footnotetext{
${ }^{11}$ Source: https://www.eia.gov/todayinenergy/detail.php?id=27152
} 


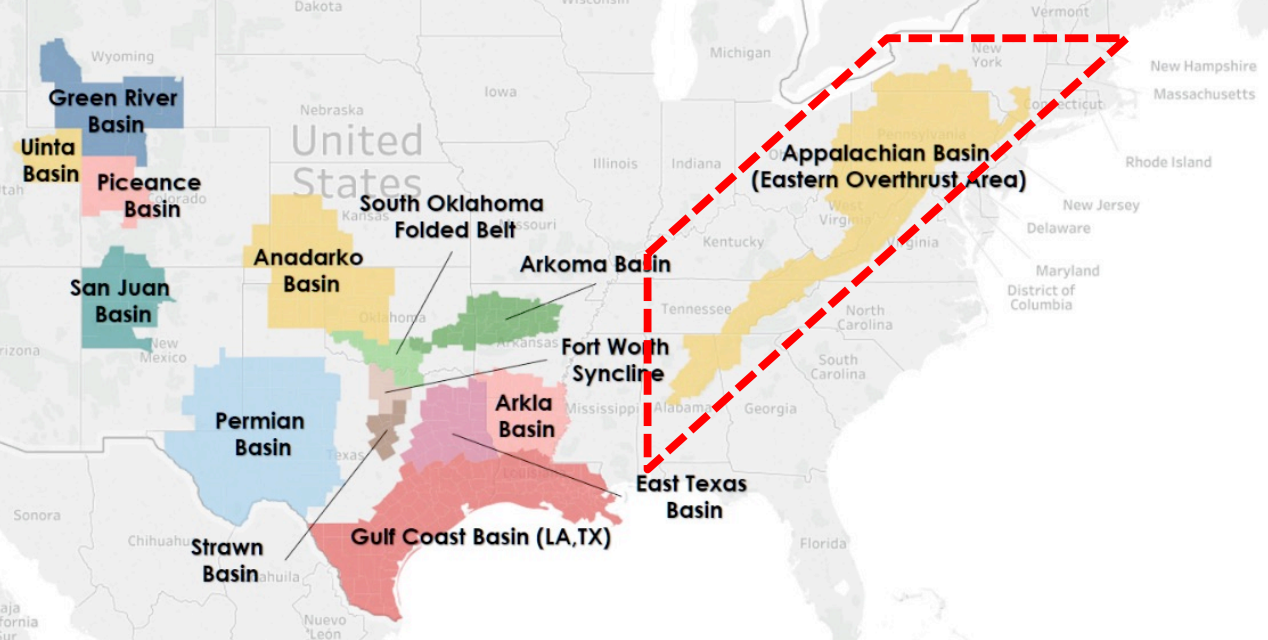

Figure 2. Basins that Account for Majority of U.S. Natural Gas Production [54]

NETL has also published LCA data for the unit process for natural gas combustion [55]. The LCA data is used to generate the LCIA results for each of the TRACI impact categories. By combining the LCIA results for natural gas delivered and its combustion, total LCIA results for the on-site use of natural gas can be calculated.

The LCI data from these "baseline" models are used to develop LCIA results consistent with the BIRDS impact category units for GWP, acidification, particulates, eutrophication, ozone depletion, and smog. Due to a lack of available data, the original data for the other impact categories is used. The resulting LCIA data is shown in Table 1.

Table 1. Operational Energy LCIA Data

\begin{tabular}{|c|c|c|c|}
\hline \multicolumn{2}{|l|}{2016 Data } & \multicolumn{2}{|c|}{ Flow Per kWh } \\
\hline Impact Category & Unit & Electricity & Direct Use Nat Gas \\
\hline Global warming & $\mathrm{kg} \mathrm{CO} 2 \mathrm{eq}$ & $6.06 \mathrm{E}-01$ & $2.51 \mathrm{E}-01$ \\
\hline Acidification & $\mathrm{mol} \mathrm{H}+\mathrm{eq}$ & $7.86 \mathrm{E}-02$ & $2.47 \mathrm{E}-02$ \\
\hline Respiratory effects & kg PM10 eq & $3.06 \mathrm{E}-04$ & $5.18 \mathrm{E}-05$ \\
\hline Eutrophication & $\mathrm{kg} \mathrm{N}$ eq & $6.38 \mathrm{E}-05$ & $3.28 \mathrm{E}-05$ \\
\hline Ozone depletion & kg CFC-11-Eq & $6.80 \mathrm{E}-09$ & $2.95 \mathrm{E}-11$ \\
\hline Smog & $\mathrm{kg} \mathrm{O} 3 \mathrm{eq}$ & $2.72 \mathrm{E}-02$ & $1.48 \mathrm{E}-02$ \\
\hline Energy & Per unit of energy & $3.64 \mathrm{E}+00$ & $2.93 \mathrm{E}+00$ \\
\hline \multicolumn{4}{|c|}{$\begin{array}{l}\text { Data uses the BIRDS impact category units. } \\
\text { The electricity baseline for PJM from the LCA Commons is used for electricity. } \\
\text { The supply chain data for the App. Basin from NETL is used for delivered natural gas. } \\
\text { The updated US LCI data provided by Four Elements for combustion of natural gas. }\end{array}$} \\
\hline
\end{tabular}

The updated data shows similar trends to the prior data used in BIRDS with electricity resulting in higher environmental impacts per unit of energy consumed on-site, but with 
lower environmental impact "premiums", with premium reductions ranging from $11 \%$ to $62 \%$ (Table 2). One of the key factors for the relative reduction is because the electricity fuel mix for PJM in 2016 included $29 \%$ coal, which is significantly lower than for the prior data. The use of a cleaner fuel mix lowers emissions and the resulting environmental impacts.

Table 2. Operational Energy Impact Ratios by Data Source

\begin{tabular}{|c|c|c|c|}
\hline Relative Emissions Rate & \multicolumn{3}{|c|}{ Electricity to Gas Ratio } \\
\hline Impact Category & $\begin{array}{l}\text { BIRDS } \\
4.0 \\
\end{array}$ & $\begin{array}{l}\text { BIRDS } \\
4.1 \\
\end{array}$ & $\begin{array}{l}\text { "Premium" } \\
\text { Change }\end{array}$ \\
\hline Global Warming & $271 \%$ & $241 \%$ & $-11 \%$ \\
\hline Eutrophication & $317 \%$ & $195 \%$ & $-39 \%$ \\
\hline Smog Potential & $478 \%$ & $184 \%$ & $-62 \%$ \\
\hline Energy & $169 \%$ & $124 \%$ & $-26 \%$ \\
\hline
\end{tabular}

Ozone Depletion is excluded because the values are so small that a small change in a single LCI flow can lead to massive changes.

It is important to note that even though the data was released in 2019 , the source data for these estimates are based on 2016 data (most recent data available at the time of development). Any changes in the electricity fuel mix or natural gas extraction and distribution would influence these estimates. For example, the PJM fuel mix for 2019 decreased to $24 \%$ coal $^{12}$. The analysis should be completed again when more recent data becomes available.

Forming overall conclusions about the environmental performance of an individual building design based on LCIAs can be difficult because each of the LCIAs are measured in different units. BIRDS addresses this through a metric that combines the performance of all twelve categories into a single numeric environmental impact score (EIS) [37]. EISs are calculated using fixed scale normalization references based on annual contributions of U.S. economic activity to the LCIA categories (Table A-8). For more information on EISs, refer to Lippiatt, Kneifel, Lavappa, Suh and Greig (37).

\subsection{Economic Performance}

BIRDS uses a life-cycle cost (LCC) methodology to evaluate the cost-effectiveness of buildings $[56,57]$. Life-cycle costing includes the discounted present value of all costs related to the construction, operation, maintenance, repairs, replacements, and residual value of a building for a given study period. When evaluating a series of alternative designs relative to a baseline building, the design alternative with the lowest LCC is the most cost-effective [51]. The difference in LCCs (i.e., Net Savings) between a baseline and alternative reveals the additional costs (or savings) incurred by the homeowner. A positive net savings (NS) implies that alternative is more cost-effective than the baseline. The generalized formula for calculating LCCs of a building is:

$$
L C C=C+O+M R R-R V
$$

The LCC estimates in this study use data from a number of sources. Initial construction costs (C) include costs of constructing the building as estimated using RS Means (58) for the typical construction cost for a single family dwelling of the particular type of building, plus

\footnotetext{
${ }^{12}$ Source: https://gats.pjm-eis.com/GATS2/PublicReports/PJMSystemMix
} 
the additional incremental costs of upgrading the design with each implemented EEM (Faithful and Gould (59), Kneifel and O'Rear (60), and local contractor quotes). Operational costs $(\mathrm{O})$ are those associated with normal functioning of the house, while maintenance, repair, and replacement costs (MRR) are related to upkeep of the structure. Residual Value $(\mathrm{RV})$ is the value left in the structure and its components at the end of the study period.

Most of the construction cost data was assumed unchanged except for an adjustment for general inflation to get all costs to 2018 dollars. The only cost data that changed significantly was the installed cost of the solar PV systems. The linear cost estimate of $\$ 3.29 / \mathrm{W}$ was replaced with a more accurate cost function based on 2018 EnergySage data that includes a fixed cost (\$1611) and a proportional cost $(\$ 2.67 / \mathrm{W})[61]$. As in the previous study, the federal tax credit is included in the LCC analysis, which decreased from $30 \%$ to $26 \%$ of total installed cost in 2020.

Maintenance, repair, and replacement rates and costs (MRR) are obtained from Census (62), Faithful and Gould (59), National Association of Home Builders (NAHB) Research Center (63), and ENERGY STAR (64). MRR costs and associated residual values (RV) are calculated for each building component with different rates of replacement than the building structure. Operational costs $(\mathrm{O})$ include estimated electricity and natural gas costs.

Operational energy costs are based on the standard residential rate schedule from PEPCO (65), annual average residential natural gas cost data for Maryland [66], and energy price escalation rates in Lavappa, Kneifel and O'Rear (67). Residual values are based on the linear depreciation method defined in ASTM (68).

For more information on the cost data and life-cycle cost approach, see Kneifel, O'Rear et al. (2018).

\subsection{Building Component Options and Analysis Assumptions}

This analysis compares the performance of a baseline building design constructed according to 2015 IECC (Maryland Code-Compliant or MCC design), to alternative building design options included in the BIRDS Database. Each alternative has its own EEM combination, which may be more (or less) efficient than the baseline design. Table 3 lists the building envelope and system specifications (excluding HVAC and DHW systems) for the baseline design.

Table 3. Maryland Code-Compliant Home Design Specifications

\begin{tabular}{|c|c|c|}
\hline Category & Specifications & $\mathrm{MCC}$ \\
\hline Windows & U-Factor and SHGC & $1.99 \mathrm{~W} / \mathrm{m}^{2}-\mathrm{K}$ and 0.40 \\
\hline $\begin{array}{l}\text { Framing and } \\
\text { Insulation }\end{array}$ & $\begin{array}{l}\text { Framing } \\
\text { Exterior Wall (finish: wood siding) } \\
\text { Basement Wall and Floor } \\
\text { Roof/Ceiling Assembly }\end{array}$ & $\begin{array}{l}5.1 \mathrm{~cm} \times 10.2 \mathrm{~cm}-40.6 \mathrm{~cm} \mathrm{OC} \\
\mathrm{R}_{\mathrm{SI}^{-}}-3.5 \text { or } \mathrm{R}_{\mathrm{SI}^{-}}-2.3+0.9 \dagger \\
\mathrm{R}_{\mathrm{SI}^{-}}-1.8 \dagger \text { and } \mathrm{R}_{\mathrm{SI}^{-0}}-0 \dagger \\
\text { Ceiling: } \mathrm{R}_{\mathrm{SI}^{-}}-8.6\end{array}$ \\
\hline Air Change Rate & $\begin{array}{l}\text { Air Change Rate }- \text { Blower Door Test } \\
\left.\text { Effective Leakage Area ( } 1^{\text {st }} \text { Floor; } 2^{\text {nd }} \text { Floor }\right)\end{array}$ & $\begin{array}{l}3.00 \mathrm{ACH}_{50} \\
403.6 \mathrm{~cm}^{2} ; 368.1 \mathrm{~cm}^{2}\end{array}$ \\
\hline Lighting & Efficient Lighting (\%) & $75 \%$ efficient built-in fixtures \\
\hline
\end{tabular}


Given that the BIRDS Database includes designs that have either electric- or natural-gas powered space heating and DHW heating systems, two types of baseline MCC designs are considered: (1) all-electric MCC design (MCC-E) and (2) MCC design with natural gaspowered space heating and DHW systems (MCC-NG). Table 4 lists HVAC and DHW specifications for MCC-E and MCC-NG.

Table 4. HVAC and DHW Specifications for Alternative Baseline Designs

\begin{tabular}{|c|c|c|c|}
\hline Category & Specifications & MCC-E & MCC-NG \\
\hline HVAC & Heating/Cooling* & $\begin{array}{l}\text { Air-to-air heat pump } \\
\text { (SEER 13.0/HSPF 7.7) }\end{array}$ & $\begin{array}{l}\text { Gas-electric split A/C system } \\
\text { (SEER } 13.0 / 80 \% \text { AFUE) }\end{array}$ \\
\hline DHW & Water Heater & $189 \mathrm{~L}$ electric $(\mathrm{EF}=0.95)$ & $189 \mathrm{~L}$ gas $(\mathrm{EF}=0.78)$ \\
\hline
\end{tabular}

The optimal alternative designs are selected based on their relative energy and economic performance under the same assumptions as applied in the prior study: $3 \%$ discount rate, $80 \%$ mortgage loan financing ( $20 \%$ down payment), average construction quality, 30 -year study period, and wood siding exterior wall finish. Currently, the BIRDS Database does not account for financial incentives, but for this analysis the Federal Solar Investment Tax Credit [69] is included because it's a significant factor in the economics of solar PV systems. The value of the tax credit decreased from $30 \%$ (used in the previous study) to $26 \%$ for 2020 and will further drop to $22 \%$ for 2021 .

\section{Results and Discussion}

This report focuses on a comparison of the changes in the results relative to O'Rear, Webb, Kneifel and O'Fallon (1) using the same methodology and the updated data. For a full discussion of the results using the original data see O'Rear, Webb, Kneifel and O'Fallon (1).

\subsection{Comparison of Maryland Code Compliant Designs}

Table 5 presents the results for the Maryland Code Compliant (MCC) designs in BIRDS for both the All Electric heating systems (E) and the Natural Gas heating systems (NG) from the prior study. The natural gas system has slightly lower construction costs while having approximately $10 \%$ lower energy costs. This leads to a lower LCC for the design with natural gas heating. In terms of environmental performance, natural gas has a lower EIS due to the fuel mix that makes up the location's electricity generation.

Table 5. Results for Maryland Code Compliant designs from [1]

\begin{tabular}{|lccc|}
\hline & Units & MCC-E & MCC-NG \\
\hline Construction Costs & U.S.\$ (2017) & 364292 & 363092 \\
\hline Energy Costs & U.S.\$ (2017) & 80570 & 72630 \\
\hline Total LCC & U.S.\$ (2017) & 358806 & 349091 \\
\hline Total Electricity Consumption & $\mathrm{kWh}$ & 706646 & 301226 \\
\hline Total Natural Gas Consumption & $\mathrm{kWh}$ & 0 & 1253802 \\
\hline EIS (BEES and EPA Advisory Board) & $\mathrm{n} / \mathrm{a}$ & 15.30 and 13.86 & 9.92 and 9.19 \\
\hline
\end{tabular}


The results using the updated data are found in Table 6. Construction costs increase due to price inflation while the energy costs decrease, driven by lower projected energy escalation rates. Overall, the LCC for both MCC designs is cheaper than the results from O'Rear, Webb, Kneifel and O'Fallon (1) due to the lower energy costs overwhelming the higher construction costs. Natural gas still maintains an edge over the all-electric design on LCC, although the difference is reduced by approximately $50 \%$. Energy consumption is unchanged from the prior study because the same simulation runs are used, showing MCC-NG consumes over twice the energy than MCC-E, driven by the relative lower efficiency of the natural gas-fired equipment. Even with the additional consumption, the relative lower cost of natural gas leads to lower overall energy costs to the homeowner. Both designs show improvement in environmental performance as measured by the EIS, with the all-electric design having the larger decrease in magnitude. These results are driven by the decrease in the environmental impacts from the new energy LCA data, with electricity realizing a greater relative decrease from the prior study. The nature of the EIS score calculations makes comparing magnitude difference infeasible, however it is meaningful that the gap between the all-electric and natural gas designs is reduced.

Table 6. Results for Maryland Code Compliant Designs using Updated Data

\begin{tabular}{|lccc|}
\hline & Units & MCC-E & MCC-NG \\
\hline Construction Costs & U.S. \$ (2019) & 368278 & 367049 \\
\hline Energy Costs & U.S. \$ (2019) & 68990 & 66304 \\
\hline Total LCC & U.S. \$ (2019) & 350546 & 346042 \\
\hline Total Electricity Consumption & $\mathrm{kWh}$ & 706620 & 301226 \\
\hline Total Natural Gas Consumption & $\mathrm{kWh}$ & 0 & 1253802 \\
\hline EIS (BEES and EPA Advisory Board) & n/a & $13.44,11.49$ & $9.08,8.10$ \\
\hline
\end{tabular}

As in the previous study, this analysis utilizes a thermal comfort metric based on ASHRAE Standard 55: number of hours for which indoor conditions do not meet thermal comfort requirements of a building's occupants [70], referred to as "total hours uncomfortable". 13 For additional information on thermal comfort in BIRDS, refer to Kneifel, Lavappa, O'Rear, Greig and Suh (71). The thermal comfort results remain identical to those from O'Rear, Webb, Kneifel and O'Fallon (1), which indicate that the MCC-E design is "less comfortable" with 622 hours where the temperature requirements were not met as compared to 152 hours for the MCC-NG design.

Figure 3 presents the radar plot from the previous study comparing the impact category results for MCC-E design to the MCC-NG design with the updated results overlayed. The MCC-NG design has the same or lower environmental impacts as the MCC-E design in every category.

\footnotetext{
${ }^{13}$ Total hours uncomfortable computed by the E+ Building Energy Simulation Software refers to the total number of hours in a year that indoor building temperatures are outside pre-defined setpoint temperature levels
} 


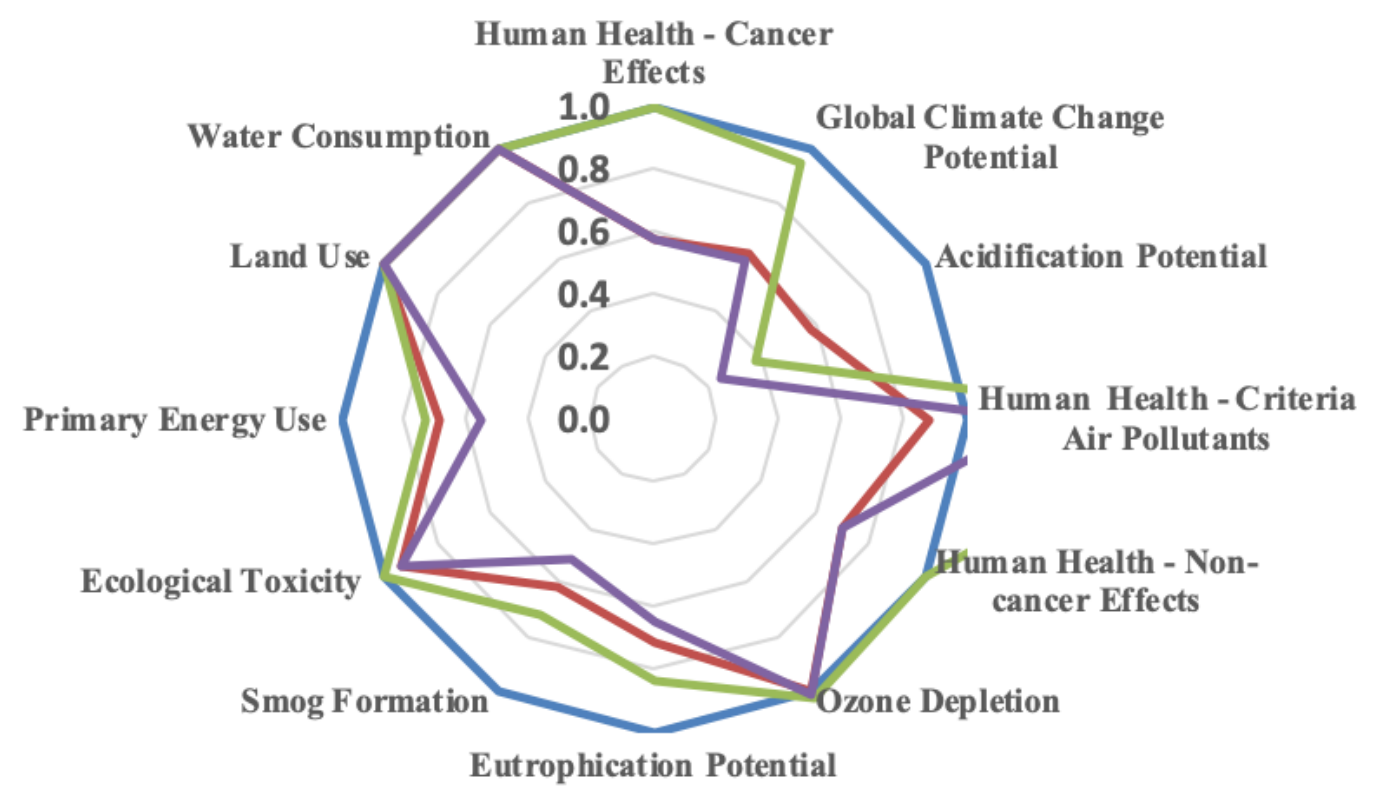

$\longrightarrow$ MCC-E Original $\longrightarrow$ MCC-NG Original

MCC-E Updated MCC-NG Updated

Figure 3. MCC-E vs. MCC-NG Designs (fractional performance relative to MCC-E Original) from [1]

Comparing the original results to the updated results show the same general trend of MCCNG outperforming MCC-E. The only differences are the relative magnitude of the outperformance. The acidification potential is now closer to parity while the air pollutants flows are diverging with natural gas being less intensive. Apart from those changes most other flows are identical, or very similar, between the older results and those using the updated data.

\subsection{All-Electric Design Results}

This section analyzes all the building designs in the BIRDS Database using electric space and water heating equipment. Figure 4 and Figure 5 display energy and economic results based on the assumptions in Section 4.4 for 240000 designs, each with a unique combination of EEMs with an assumed location of Gaithersburg, MD and identical usage patterns. Each data point includes either Option 1 or Option 2 for space heating (Table A-5), as well as one of the first four options for domestic water heating (Table A-6). The horizontal axis is the fractional reduction in total energy use relative to the code-compliant design (MCC-E), while the vertical axis is the change in LCC relative to the MCC-E design. All data points located on or to the right of the NZ-boundary line (blue) are building designs that perform at net-zero (site production equals or exceeds site consumption) or better over the 30 -year study period. 
The plot of all results from the previous study is shown in Figure 4. A decrease in net energy use is correlated with a decrease in LCC until net-zero energy performance is achieved, at which point LCC begin to increase due to a discontinuity in the compensation between offset energy usage (retail electricity price) and compensation for excess generation (avoided cost to the utility). The updated data (Figure 5) shows the same trend with a slight flattening of the slope of the data. This flatter trend is a result of the increase in construction costs when combined with reductions in the energy cost savings over time. In all, the LCC for the costoptimal designs for given energy reductions are higher for the updated data by approximately $\$ 5000$. Note that some of this increase is a result of general inflation from 2016 to 2018 dollars.

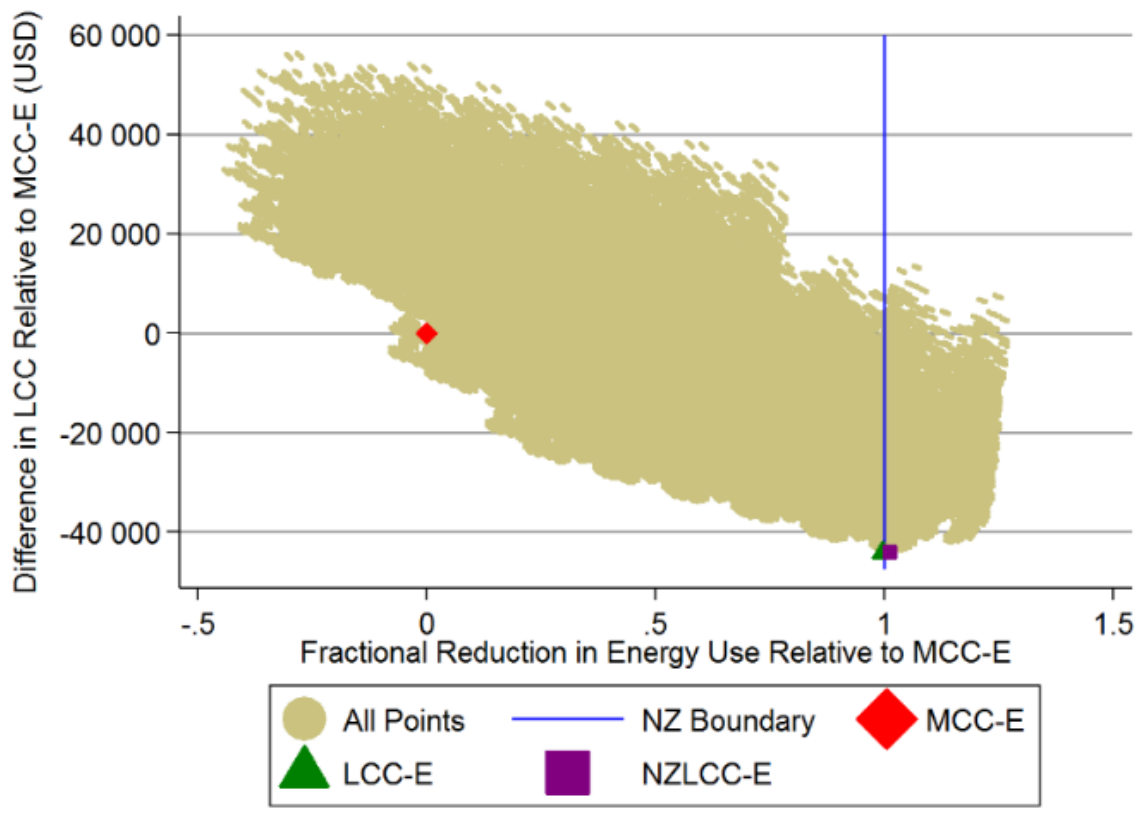

Figure 4. All-Electric Designs from [1] 


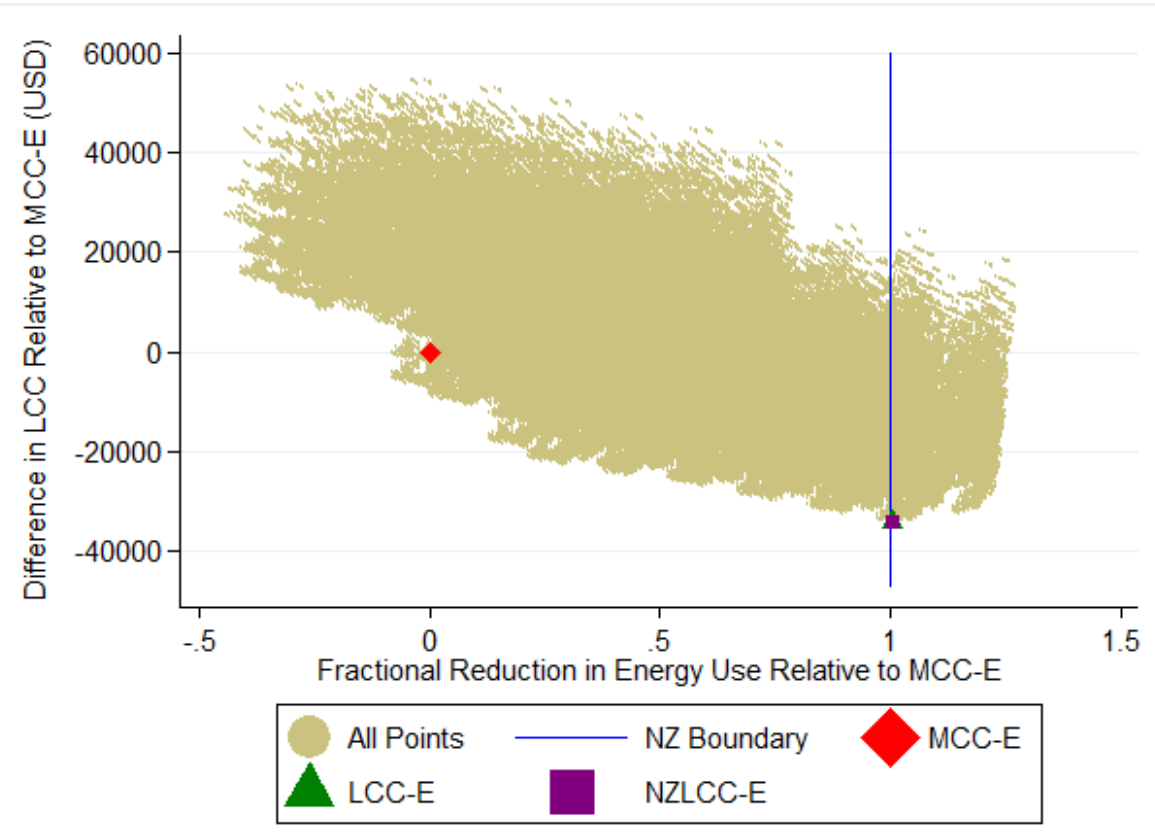

Figure 5. All-Electric Designs using Updated Data

The optimization curves from O'Rear, Webb, Kneifel and O'Fallon (1) are presented in Figure 6. The downward trend evident in Figure 4 is also seen in the plot of both the HVAC system and DHW curves. The higher efficiency HVAC systems tend to be on par in terms of LCC than the low efficiency systems but achieve higher energy efficiencies along the curve, while being slightly more costly if all other EEMs are held constant. The performance of the DHW systems are less differentiated, but the solar thermal heating system leads to higher LCC while offering only slightly more efficient energy consumption. Figure 7 shows the same curves for the updated data. The curves are flatter for the designs with the lowest LCC, mirroring the effect of Figure 5 relative to Figure 4, while retaining the fast rise in diminished value after reaching net-zero. The general inferences of the previous paper remain intact, namely that air change rate is the largest driver for energy efficiency and LCC, while HVAC system provides a meaningful, but smaller, impact. 


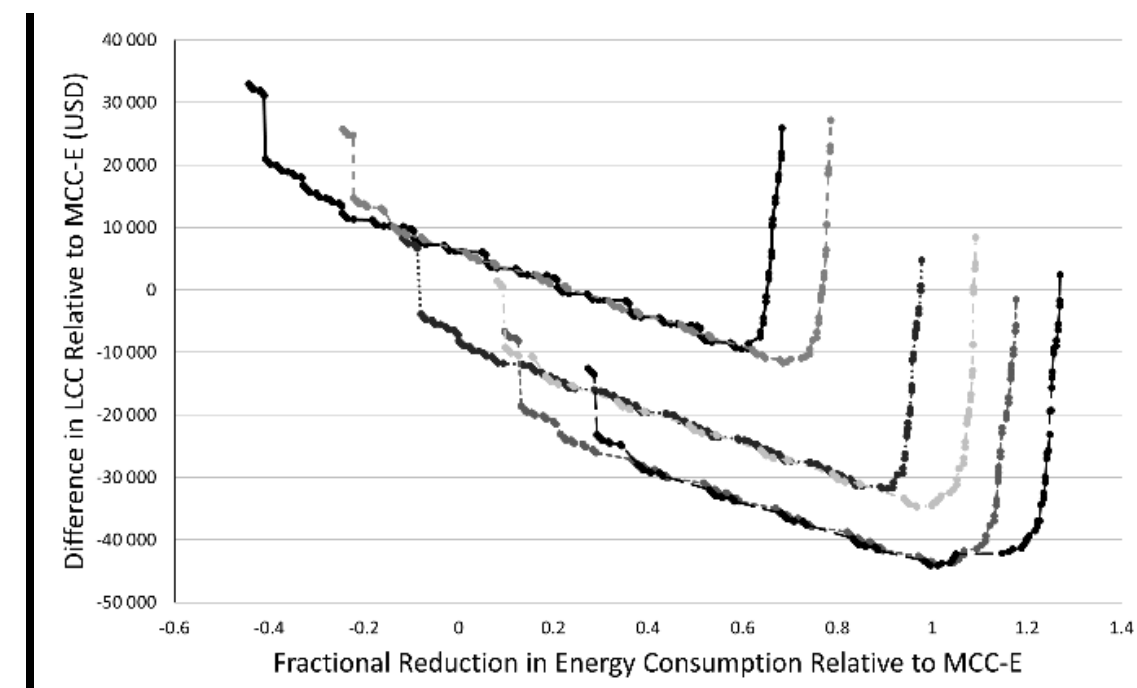

$\rightarrow$ 1. HP Std Eff. NOA-7 ACH … 2. HP td Eff. OA-3 ACH ---3. HP Std Eff. OA-0.63 ACH

- 4. HP High Eff. HRV-7 ACH - 5. HP High Eff. HRV-3 ACH $\rightarrow-6$. HP High Eff. HRV-0.63 ACH

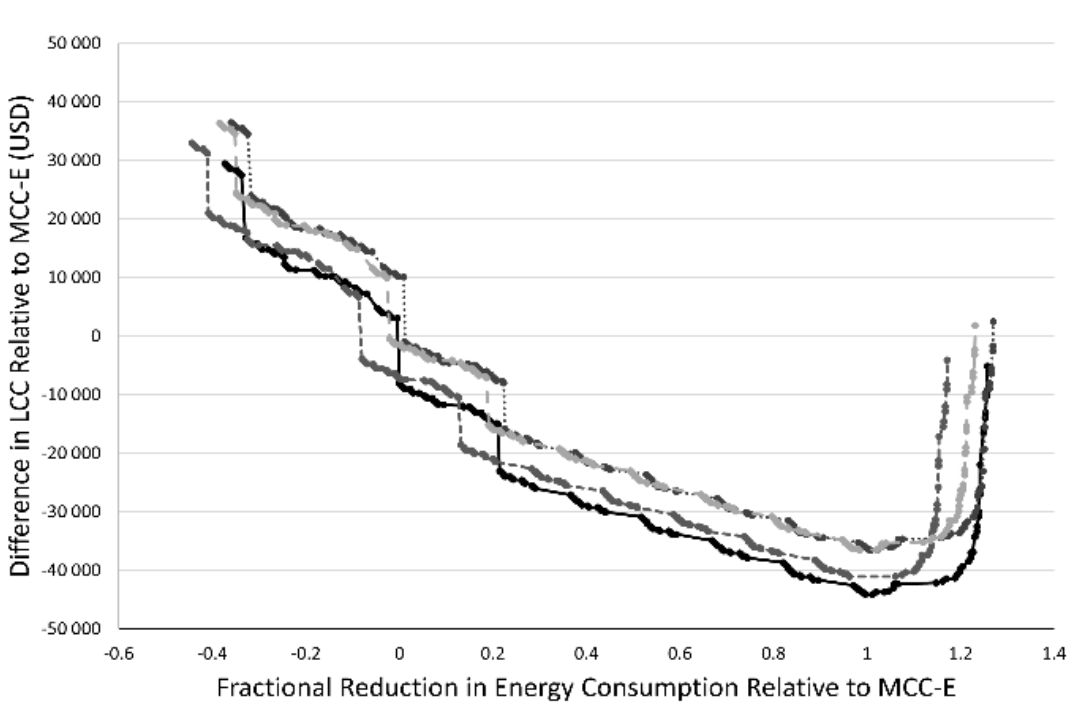

$$
\begin{array}{ll}
\rightarrow \text { 1. Heat Pump } & \cdots \cdots 2 \text {. Heat Pump w/ Solar Thermal } \\
\cdots-3 \text {. Electric Resistance } & -\infty \text { 4. Electric Resistance w/ Solar Thermal }
\end{array}
$$

Figure 6. Optimization Curves for All-Electric Designs based on (a) HVAC System and (b) DHW System from [1] 

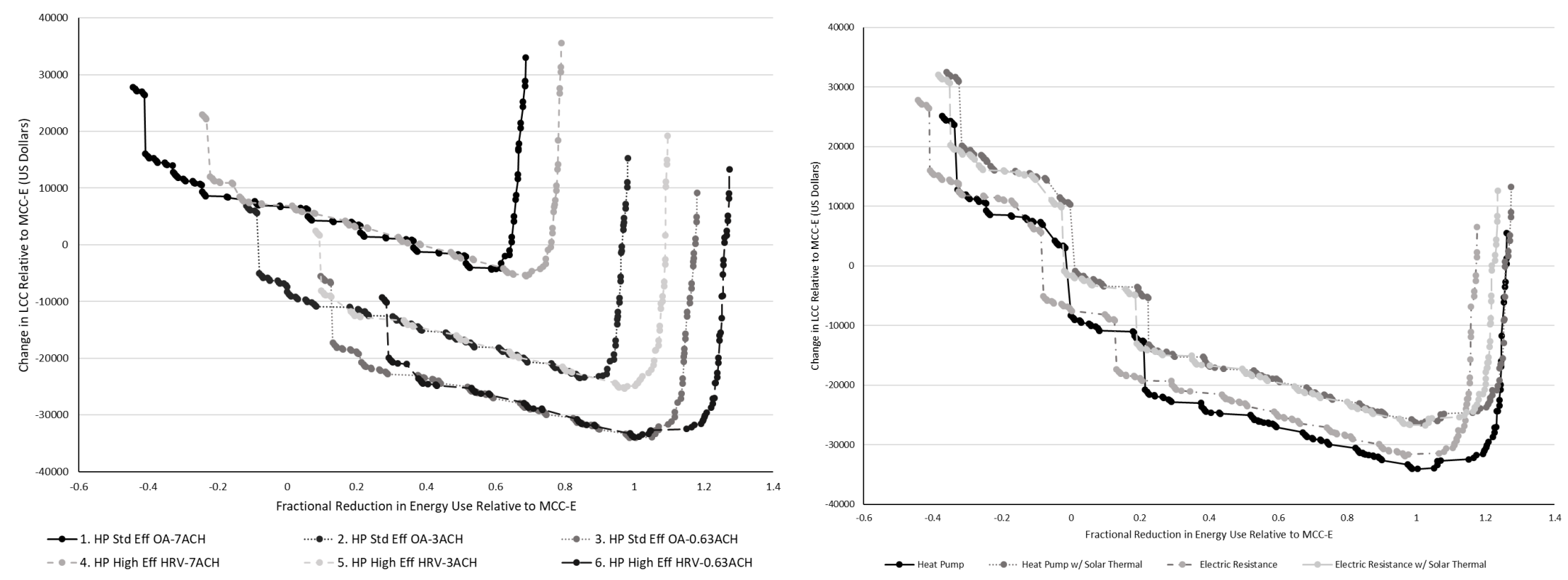

Figure 7. Optimization Curves for All-Electric Designs based on (a) HVAC System and (b) DHW System using Updated Data 
Figure 8 and Figure 9 contain the plot for all designs separated by PV system from O'Rear, Webb, Kneifel and O'Fallon (1) and using the updated data, respectively. Aside from the flattening of the slope on the lower LCC values which has already been mentioned, the general observations from O'Rear, Webb, Kneifel and O'Fallon (1) are unchanged. First, Solar PV is a necessary EEM to substantially lower net energy usage. Second, the solar PV system must be at least $10.2 \mathrm{~kW}$ (if limiting options to those discrete sizes that exist in the database) to achieve net-zero performance.

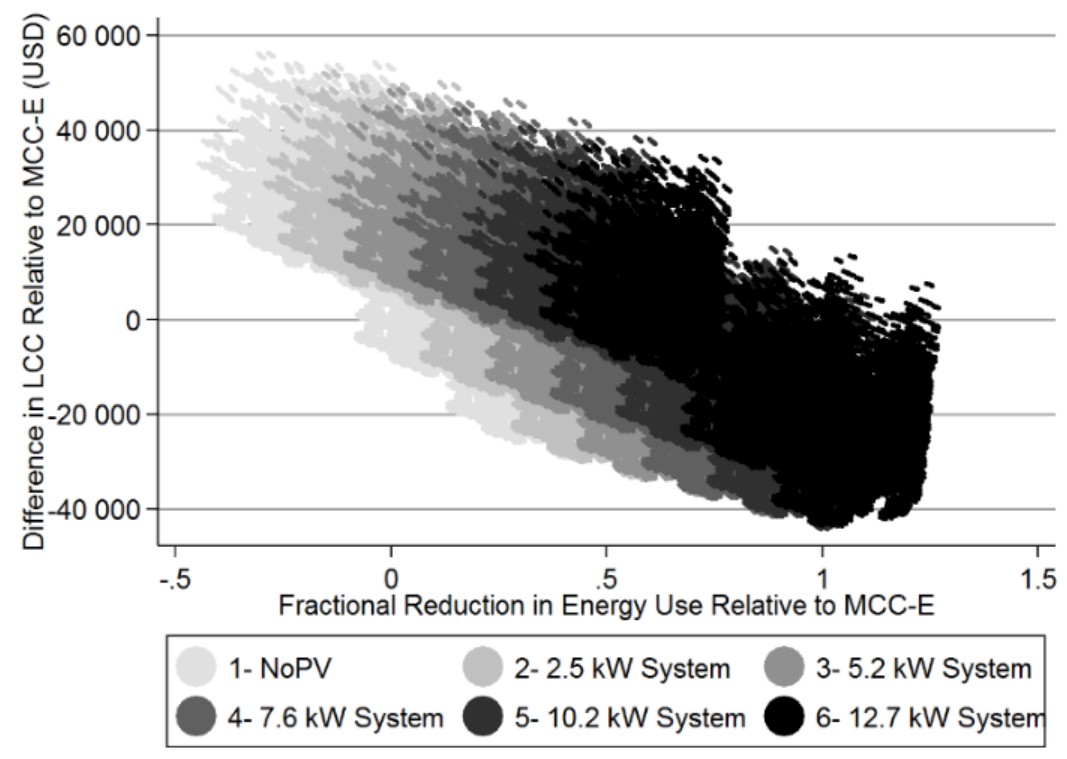

Figure 8. All-Electric Designs based on Solar PV System Capacities from [1]

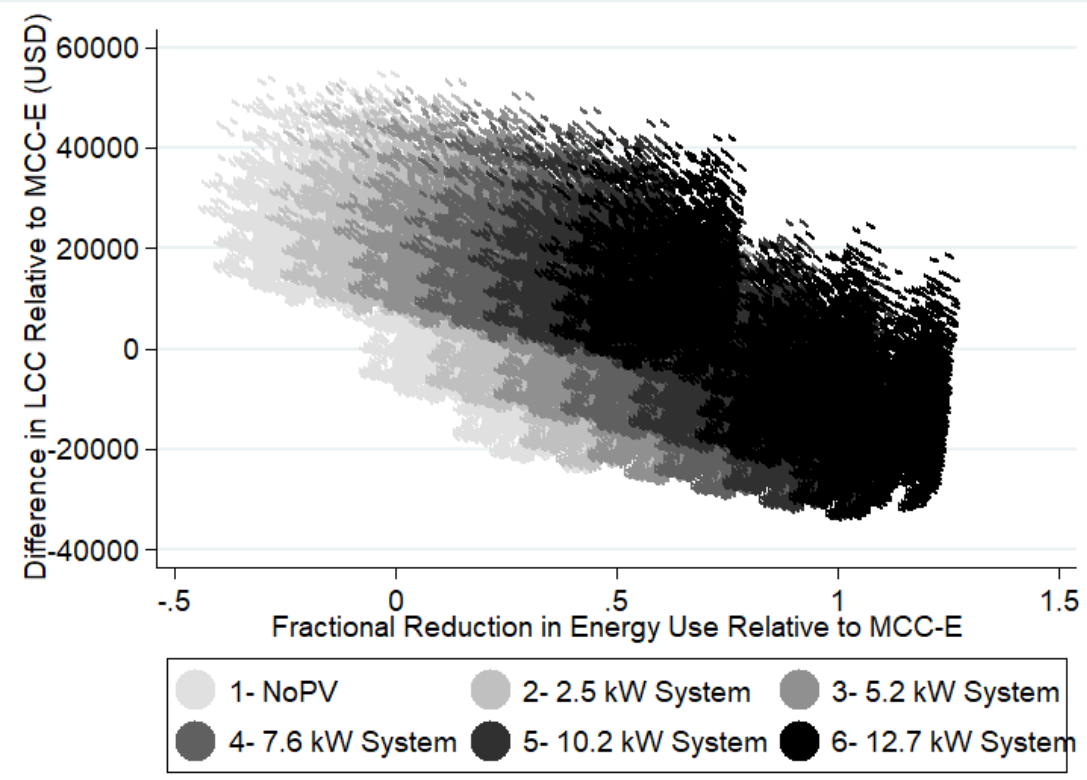

Figure 9. All-Electric Designs based on Solar PV System Capacities using Updated Data 


\subsection{Gas Design Results}

This section analyzes the building designs using gas-fired HVAC and DHW equipment. Four key building designs are identified and will be discussed later: (1) gas-heated, codecompliant design (MCC-NG), (2) gas-heated, lowest cost design (LCC-NG), (3) gas-heated, net-zero energy design at least cost (NZLCC-NG) and (4) gas-heated but with net-zero site electricity design at least cost (LNZE-NG).

Figure 10 presents the relative LCC performance of all designs using natural gas for heating from O'Rear, Webb, Kneifel and O'Fallon (1) relative to (a) reduction in total energy consumption and (b) reduction in electricity consumption. Both the LCC-NG and LNZE-NG designs are the same design. When compared to the all-electric designs in Figure 4, the distribution is similar, but with the cost-optimal design occurring at $\approx 77 \%$ reduction in site energy consumption instead of $\approx 101 \%$ and with far fewer designs meeting the net-zero threshold. In fact, only the NZLCC-NG design is located beyond the NZ-Boundary (blue). This is a result of three factors: (1) higher initial total site energy use by the MCC-NG design, (2) smaller potential savings from heating equipment, and (3) relative cost of natural gas to electricity in combination with the net metering structure. Fewer designs can reach net-zero energy performance because greater reductions in energy use are required while the efficiency improvements in heating equipment are smaller for natural-gas fired equipment relative to electric equipment. Electricity production from solar PV is cost-effective in reducing net energy consumption to the point of offsetting all electricity consumption. However, as discussed earlier, the value of excess electricity production is lower than the value of reducing electricity consumption. Additionally, the relative cost of natural gas is much lower than electricity, leading to it being not cost-effective to reduce natural gas consumption using excess production. As a result, the LCC-optimal design (LCC-NG) is located just beyond net-zero electricity consumption.

Figure 11 provides the same comparison as Figure 10, but for the updated data. As with the all-electric results, the increase in construction costs causes the slope of the lower LCC designs to flatten slightly, although the difference is less pronounced for the natural gas systems. Otherwise, all the same general results hold.
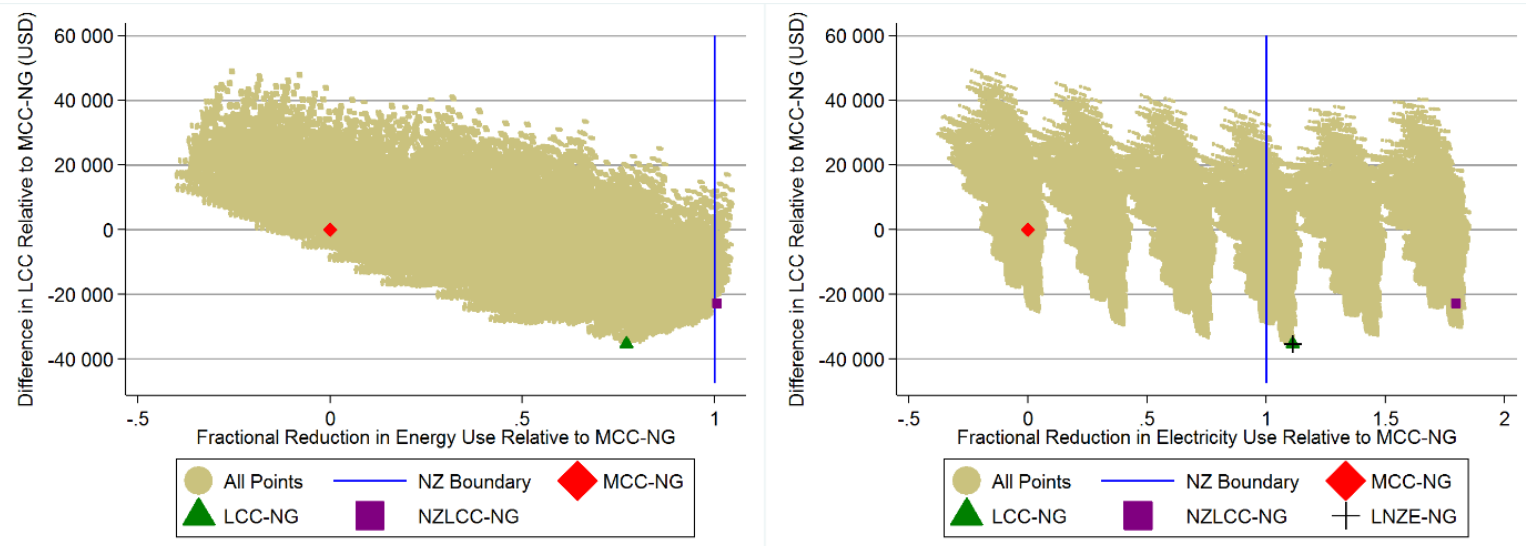

Figure 10. Gas-heated Designs based on Fractional Reduction in (a) Total Energy Use and (b) Electricity Use from [1] 

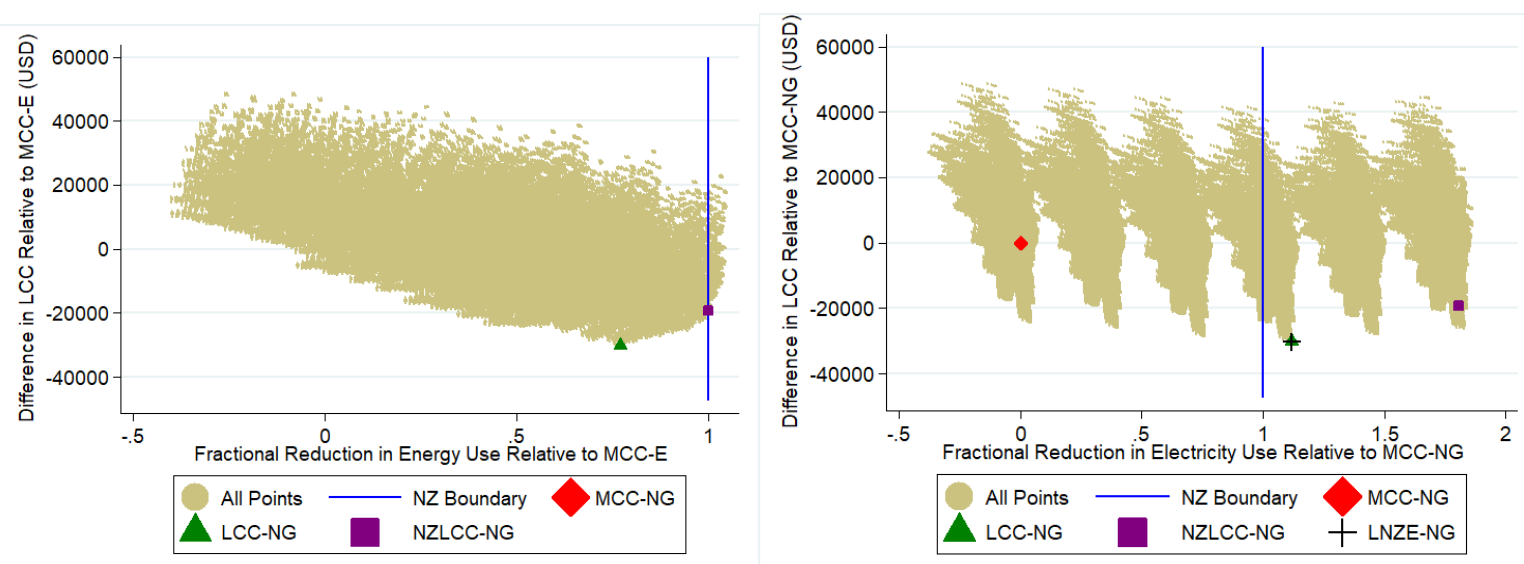

Figure 11. Gas-heated Designs based on Fractional Reduction in (a) Total Energy Use and (b) Electricity Use using Updated Data

Figure 12 illustrates the LCC optimization curves from the previous study for each level of net site energy reduction for six alternative configurations for the gas-fired HVAC system, varying based on efficiency, method and rate of ventilation, and air leakage rate. Like the analysis of the all-electric design cases, a building envelope having a low air leakage rate (0.63 ACH@50 Pa) AND a high-efficiency split AC and HRV system (Setup 6), are the primary drivers behind the reductions in net energy use for all designs performing at or beyond net-zero energy. Although large reductions in net energy use are attainable with a high efficiency split system (Setup 4 and Setup 5), similar, less costly reductions can be attained when the standard efficiency system is paired with a building envelope having a leakage rate of $0.63 \mathrm{ACH} @ 50 \mathrm{~Pa}$ (Setup 3). In order to reach net zero energy performance, DHW system must include the high efficiency gas-fired water heater (Setup 3 or Setup 4). The inclusion of a solar thermal system produces additional but marginal reductions in net energy use, but at a greater LCC to the homeowner. Aside from the upward shift in the lower LCC values, the results using the updated data (Figure 13) show the same general trends. 


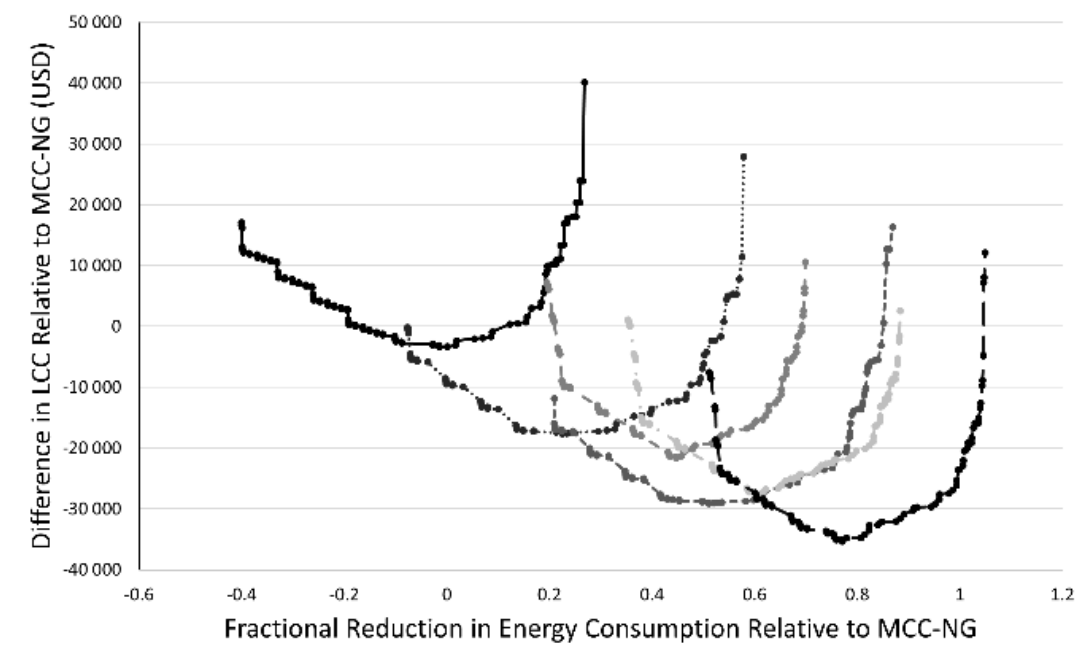

$\rightarrow$ 1. Split AC Sys. Std Eff. NOA-7 ACH

3. Split AC Sys. Std Eff. OA-0.63 ACH

- 5. Split AC Sys. High Eff. HRV-3 ACH

.... 2. Split AC Sys. Std Eff. OA-3 ACH - 4. Split AC Sys. High Eff. HRV-7 ACH $\rightarrow-6$. Split AC Sys. High Eff. HRV-0.63 ACH

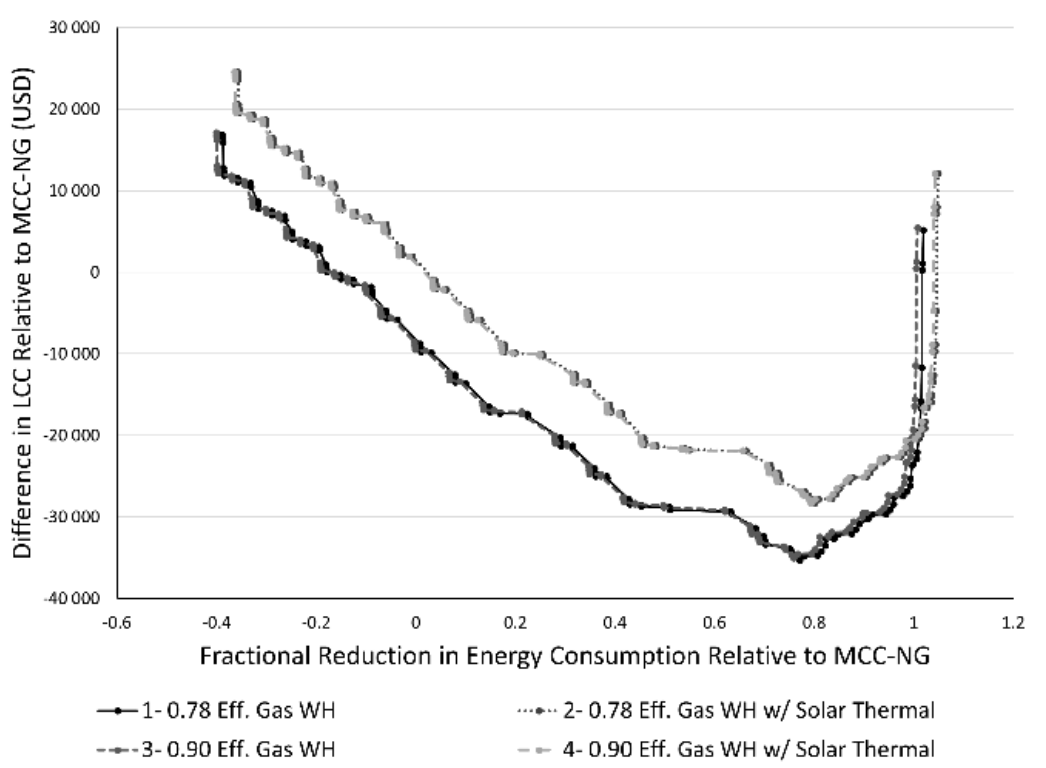

Figure 12. Optimization Curves for Gas-heated Designs based on (a) HVAC System and (b) DHW System from [1] 

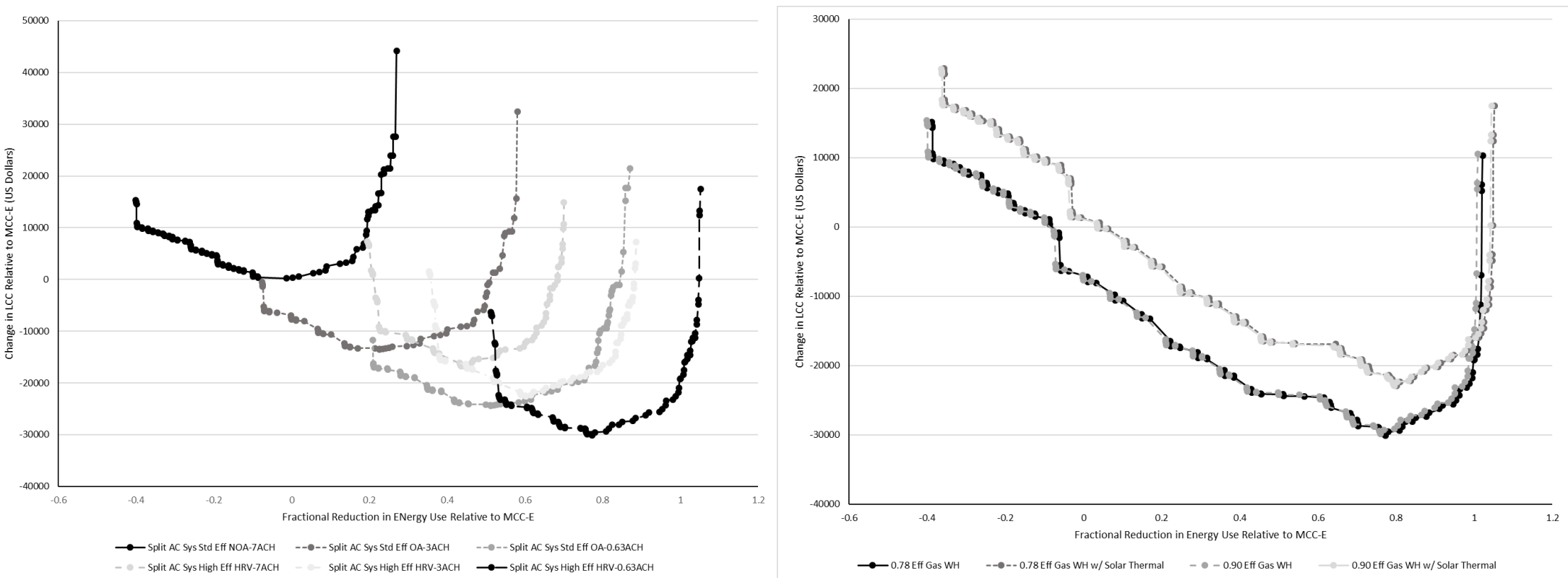

Figure 13. Optimization Curves for Gas-heated Designs based on (a) HVAC System and (b) DHW System using Updated Data 


\subsection{Cross-comparisons of selected building designs}

This section discusses differences between key electric and gas heating system options based on combinations of EEMs, energy, and economic performance.

Table 7 describes the design characteristics of the four key building designs from O'Rear, Webb, Kneifel and O'Fallon (1), while Table 8 does the same for the updated data. For all four key designs, air leakage performance, lighting, DHW, walls, foundation wall, and foundation floor are identical in the two studies. The windows are the same for LCC-E, LCCNG, and NZLCC-E while NZLCC-NG installs a less efficient window. The roof assembly is the same for LCC-NG, NZLCC-E, NZLCC-E while LCC-E includes more insulation.

The most noticeable changes are for LCC-E and NZLCC-E, which are now identical. Considering how similar the designs were in the prior study, it is not unexpected that the minor changes in the cost data lead to a shift in the specific EEMs included in the updated results. Both designs increase the size of the installed solar PV system while using the less efficient available HVAC system. The decrease in the marginal cost of installing the additional $2.7 \mathrm{~kW}$ of solar PV now makes it more cost-effective than installing the more efficient HVAC system to reach net-zero performance. The LCC-NG result is consistent between the data sets and is the only design that does not include the largest solar PV system available. Even with the minor changes in the selected EEMs, energy consumption values are nearly identical for all four designs relative to the prior study (within $1 \%$ ).

The difference in total hours uncomfortable across the two LCC designs is negligible, suggesting that the LCC-E design is equally as comfortable as the LCC-NG design with the exception of the NZLCC-NG design, which has roughly 150 less hours uncomfortable compared to the NZLCC building and an additional benefit of roughly 100 hours over the allelectric designs.

As in the previous study, net-zero energy performance is reached at the lowest LCC using an all-electric design (NZLCC-E). Reaching net zero using natural gas heating requires additional EEM installations because of higher on-site heating energy consumption. The incremental increase in initial construction costs relative to the code-compliant design in Maryland (MCC-E) is \$28 222, which continues a decreasing trend in estimates using the BIRDS database. For example, the BIRDS 4.0 database estimates the same additional construction costs at $\$ 34659$. There are two reasons for this result: (1) solar PV has become so relatively cheap to install that the optimal solar PV installation leads to less efficient building envelope selections than is required by the prescriptive path in Maryland code. The $12.7 \mathrm{~kW}$ solar PV system, after subtracting the tax credit, costs \$26 285. The other EEMs implemented to reach net-zero are replacing light bulbs with LEDs, installing a heat pump water heater, reducing the air leakage rate, and adding slightly more insulation in the roof assembly. Much of the additional costs of these additional EEMs is offset by lower costs by installing less efficient windows and wall assemblies. Over the 30-year study period, NZLCC-E saves the homeowner \$34 063. Although the homeowner could save more by designing to meet the lowest LCC design using natural gas heating (LCC-NG), the additional savings is only $\$ 527$ (over 30 years) while still consuming about $50 \%$ of the site energy relative to that of the MCC-E. 
Table 7. Design Features for All-Electric and Gas-heated EE and LCC Building Designs from [1]

\begin{tabular}{|c|c|c|c|c|}
\hline Design Category & LCC-E & LCC-NG & NZLCC-E & NZLCC-NG \\
\hline $\begin{array}{l}\text { Windows (U; } \\
\text { SHGC) }\end{array}$ & $2.56 \mathrm{~W} / \mathrm{m}^{2}-\mathrm{K} ; 0.60$ & $2.56 \mathrm{~W} / \mathrm{m}^{2}-\mathrm{K} ; 0.60$ & $2.56 \mathrm{~W} / \mathrm{m}^{2}-\mathrm{K} ; 0.60$ & $1.99 \mathrm{~W} / \mathrm{m}^{2}-\mathrm{K} ; 0.60$ \\
\hline Heating \& Cooling & $\begin{array}{c}\text { SEER 13.0/ HSPF } \\
7.7\end{array}$ & $\begin{array}{c}\text { SEER 16.0/ AFUE } \\
96 \%\end{array}$ & $\begin{array}{c}\text { SEER 13.0/ HSPF } \\
7.7\end{array}$ & SEER 16.0/ AFUE 96\% \\
\hline Ventilation & Separate HRV & Separate HRV & Separate HRV & Separate HRV \\
\hline Air Leakage & $0.63 \mathrm{ACH}_{50}$ & $0.63 \mathrm{ACH}_{50}$ & $0.63 \mathrm{ACH}_{50}$ & $0.63 \mathrm{ACH}_{50}$ \\
\hline Lighting & $\begin{array}{l}100 \% \text { efficient } \\
\text { fixtures }\end{array}$ & $100 \%$ efficient fixtures & $\begin{array}{l}100 \% \text { efficient } \\
\text { fixtures }\end{array}$ & $100 \%$ efficient fixtures \\
\hline Solar PV & $10.2 \mathrm{~kW}$ & $7.6 \mathrm{~kW}$ & $10.2 \mathrm{~kW}$ & $12.7 \mathrm{~kW}$ \\
\hline DHW & Heat Pump & Gas $-90 \%$ & Heat Pump & Gas $-90 \%$ \\
\hline Roof & Ceiling: $\mathrm{R}_{\mathrm{SI}^{-}}-6.7$ & Roof: $\mathrm{R}_{\mathrm{SI}}-7.92+0.7$ & Roof: $\mathrm{R}_{\mathrm{SI}}-7.92+0.7$ & Roof: $\mathrm{R}_{\mathrm{SI}}-7.92+0.7$ \\
\hline Wall & $\begin{array}{c}\text { Typical Frame } \mathrm{R}_{\mathrm{SI}}- \\
2.3\end{array}$ & Typical Frame $\mathrm{R}_{\mathrm{SI}}-2.3$ & $\begin{array}{c}\text { Typical Frame } \mathrm{RSI}^{-} \\
2.3\end{array}$ & $\begin{array}{c}\text { Advanced Frame } \mathrm{RSI}^{-} \\
3.5+4.2\end{array}$ \\
\hline Found. Wall & $\mathrm{R}_{\mathrm{SI}^{-}}-1.41$ & $\mathrm{R}_{\mathrm{SI}^{-}} 1.41$ & $\mathrm{R}_{\mathrm{SI}^{-}}-1.41$ & $\mathrm{R}_{\mathrm{SI}^{-}}-1.41$ \\
\hline Found. Floor & $\mathrm{R}_{\mathrm{SI}^{-}} \mathrm{O}$ & $\mathrm{R}_{\mathrm{SI}^{-}}-0$ & $\mathrm{R}_{\mathrm{SI}^{-}}-0$ & $\mathrm{R}_{\mathrm{SI}^{-}} 0$ \\
\hline Site Energy (kWh) & $\approx 2,435$ & $\approx 355,880$ & $\approx-7,908$ & $\approx-9,628$ \\
\hline Total LCC & $\$ 324,760$ & $\$ 321,259$ & $\$ 324,779$ & $\$ 338,733$ \\
\hline $\begin{array}{c}\text { Energy Savings vs } \\
\text { MCC-NG* }\end{array}$ & - & $\approx 77 \%$ & - & $\approx 101 \%$ \\
\hline $\begin{array}{c}\Delta \text { LCC vs MCC- } \\
\text { NG* }^{*} \\
\end{array}$ & - & $-\$ 35,325$ & - & $-\$ 22,880$ \\
\hline $\begin{array}{c}\text { Energy Savings vs } \\
\text { MCC-E }\end{array}$ & $99.7 \%$ & $\approx 50 \%$ & $\approx 101 \%$ & $\approx 101 \%$ \\
\hline$\Delta$ LCC vs MCC-E* & $-\$ 44,103$ & $-\$ 45,040$ & $-\$ 44,084$ & $-\$ 32,595$ \\
\hline Hrs Uncomfort./Yr & $\approx 307$ & $\approx 309$ & $\approx 262$ & $\approx 145$ \\
\hline \multicolumn{5}{|l|}{ *30-yr study period } \\
\hline
\end{tabular}


Table 8. Design Features for All-Electric and Gas-heated EE and LCC Building Designs using Updated Data

\begin{tabular}{|c|c|c|c|c|}
\hline Category & LCC-E & LCC-NG & NZLCC-E & NZLCC-NG \\
\hline Windows (U; SHGC) & $2.56 \mathrm{~W} / \mathrm{m}^{2}-\mathrm{K} ; 0.60$ & $2.56 \mathrm{~W} / \mathrm{m}^{2}-\mathrm{K} ; 0.60$ & $2.56 \mathrm{~W} / \mathrm{m}^{2}-\mathrm{K} ; 0.60$ & $2.28 \mathrm{~W} / \mathrm{m}^{2}-\mathrm{K} ; 0.60$ \\
\hline Heating \& Cooling & $\begin{array}{c}\text { SEER 13.0/ HSPF } \\
7.7\end{array}$ & $\begin{array}{c}\text { SEER 16.0/ AFUE } \\
96 \%\end{array}$ & $\begin{array}{c}\text { SEER 13.0/ HSPF } \\
7.7\end{array}$ & SEER 16.0/ AFUE 96\% \\
\hline Ventilation & Outdoor Air & Separate HRV & Outdoor Air & Separate HRV \\
\hline Air Leakage & $0.63 \mathrm{ACH}_{50}$ & $0.63 \mathrm{ACH}_{50}$ & $0.63 \mathrm{ACH}_{50}$ & $0.63 \mathrm{ACH}_{50}$ \\
\hline Lighting & $\begin{array}{l}100 \% \text { efficient } \\
\text { fixtures }\end{array}$ & $\begin{array}{l}100 \% \text { efficient } \\
\text { fixtures }\end{array}$ & $\begin{array}{l}100 \% \text { efficient } \\
\text { fixtures }\end{array}$ & $100 \%$ efficient fixtures \\
\hline Solar PV & $12.7 \mathrm{~kW}$ & $7.6 \mathrm{~kW}$ & $12.7 \mathrm{~kW}$ & $12.7 \mathrm{~kW}$ \\
\hline DHW & Heat Pump & Gas $-90 \%$ & Heat Pump & Gas - 90\% \\
\hline Roof & RSI-7.92+0.7 & RSI-7.92+0.7 & RSI-7.92+0.7 & RSI-7.92+0.7 \\
\hline Wall & $\begin{array}{c}\text { Typical Frame Rsı- } \\
2.3\end{array}$ & Typical Frame Rsı-2.3 & $\begin{array}{c}\text { Typical Frame Rsı- } \\
2.3\end{array}$ & $\begin{array}{c}\text { Advanced Frame RsI- } \\
3.5+4.2\end{array}$ \\
\hline Found. Wall & RSI-1.41 & RSI-1.41 & RSI-1.41 & RSI-1.41 \\
\hline Found. Floor & RSI-0 & RSI-0 & RSI-0 & RSI-0 \\
\hline Site Energy (kWh) & $\approx-2796$ & $\approx 355880$ & $\approx-2796$ & $\approx-\$ 2230$ \\
\hline Total LCC & $\$ 316483$ & $\$ 315956$ & $\$ 316483$ & $\$ 326876$ \\
\hline $\begin{array}{c}\text { Energy Savings vs } \\
\text { MCC-NG* }\end{array}$ & - & $\approx 77 \%$ & - & $\approx 100 \%$ \\
\hline$\Delta$ LCC vs MCC-NG* & - & $-\$ 31839$ & - & $-\$ 22008$ \\
\hline $\begin{array}{c}\text { Energy Savings vs } \\
\text { MCC-E }\end{array}$ & $\approx 100 \%$ & $\approx 50 \%$ & $\approx 100 \%$ & $\approx 100 \%$ \\
\hline$\Delta$ LCC vs MCC-E* & $-\$ 34063$ & $-\$ 34590$ & $-\$ 34063$ & $-\$ 23670$ \\
\hline Hrs Uncomfort./Yr & $\approx 415$ & $\approx 309$ & $\approx 415$ & $\approx 155$ \\
\hline
\end{tabular}

As in the previous study, the overall environmental performance using the EIS shows that the natural gas designs lead to lower environmental impacts (Table 9). As discussed previously, the electricity fuel mix for the PJM Balancing Authority remains "dirtier" than natural gas, leading to higher environmental impacts even when comparing a net-zero energy all-electric design (NZLCC-E) to a natural-gas heated building designed for cost-optimization (LCC-NG). It is difficult to compare these EIS results to the previous study on a total magnitude basis.

Table 9. Environmental Impact Score (EIS) by Key Design and Weighting Approach

\begin{tabular}{|c|c|c|c|c|c|}
\hline \multicolumn{2}{|c|}{ Weighting } & LCC-E & LCC-NG & NZLCC-E & NZLCC-NG \\
\hline $\begin{array}{l}\text { Updated } \\
\text { Database }\end{array}$ & BEES & 7.40 & 6.26 & 7.40 & 4.94 \\
\cline { 2 - 6 } & EPA & 7.07 & 6.05 & 7.07 & 5.08 \\
\hline \multicolumn{4}{|l|}{ *30-yr study period }
\end{tabular}




\section{Conclusion, Implications and Future Research}

To maintain the relevance of BIRDS, regular updates to the baseline data are required. It's ability to produce results that are not just accurate, but also meaningful, to users is dependent on the underlying environmental and cost data as well as keeping up with emerging technologies. Recent updates to the underlying cost and environmental data have recently been implemented. As both a validation of these changes and an analysis of changes created in the data, the results of O'Rear, Webb, Kneifel and O'Fallon (1) have been reproduced using the new dataset.

The updated cost and environmental data have a minor impact on the total LCC and the LCA results. Cost changes shift the slope of the LCC against relative energy efficiency slightly upward. Natural gas effects are slightly less in magnitude compared to the all-electric LCC, while relative environmental effects are more pronounced in the all-electric data. Updating the data does shift a few EEMs in optimal designs. The reduction in solar PV installation costs leads to the largest system size $(12.7 \mathrm{~kW})$ being utilized in LCC designs, further increasing the ability to achieve energy reductions cost efficiently. However, the magnitude of these benefits is decreased due to the increased construction costs and lower federal solar tax credit.

As in the previous study, net-zero energy performance is reached at the lowest LCC using an all-electric design (NZLCC-E). Reaching net zero using natural gas heating requires additional EEM installations because of higher on-site heating energy consumption. The incremental increase in initial construction costs relative to the code-compliant design in Maryland (MCC-E) is $\$ 28222$, which has continued to decrease relative to previous estimates based on previous versions of the BIRDS database. For example, BIRDS 4.0 estimated the net-zero energy design to have an additional initial construction costs of $\$ 35000$ relative to 2015 IECC. Other studies of the NIST NZERTF, which relied on the as-constructed specifications of the NZERTF, estimated the additional construction costs as high as $\$ 130000$.

The reason for these decreasing additional costs is that solar PV has become so relatively cheap to install that the optimal solar PV installation leads to less efficient building envelope selections than is required by the prescriptive path in Maryland code. The $12.7 \mathrm{~kW}$ solar PV system, after subtracting the tax credit, accounts for $93 \%$ of these additional costs (\$26 285). The other EEMs implemented to reach net-zero are replacing light bulbs with LEDs, installing a heat pump water heater, reducing the air leakage rate, and adding slightly more insulation in the roof assembly. Much of the additional costs of these additional EEMs (all but $\$ 1937$ ) is offset by lower costs from installing less efficient windows and wall assemblies.

Over the 30-year study period, NZLCC-E saves the homeowner \$34 063. Although the homeowner could save more designing to meet the lowest LCC design using natural gas heating (LCC-NG), the additional savings is only $\$ 527$ while still consuming about $50 \%$ of the site energy of the MCC-E.

The implications of on-site generation from solar PV being cheaper than reducing on-site consumption is unexpected because conventional wisdom in reaching net-zero has been to decrease energy consumption as much as possible and then install solar PV to offset the 
consumption that could not be eliminated. The concept of low-energy buildings must be reconsidered to determine whether new targets should be set, such as a combination of total consumption and net consumption or net-zero goals that include embodied energy. For example, the goal could be set as a $50 \%$ reduction in total annual consumption relative to code-compliance in combination with a net-zero on-site consumption goal. Alternatively, net-zero can be defined as the sum of operational energy and embodied energy. These results are limited in their generalization because they are based on a case study using validated simulation models based on in-situ performance of the NIST NZERTF located in Gaithersburg, MD. The implications should not be extrapolated to buildings with different climates, energy costs, building codes, or occupancies. The assumptions on the economic analysis are also important factors to consider when using the results and implications in this study for decision making. The baseline building designs in this study are based on 2015 IECC. Maryland has since adopted the 2018 IECC, which would influence the relative differences between the optimal designs and the baseline.

Construction costs and environmental impacts of building materials and energy consumption will inevitably change over time, requiring the BIRDS database to be maintained in an ongoing process to keep it up to date. BIRDS is currently limited by its available EEMs and the need to maintain construction cost and building LCA data. For example, the average installed cost of solar PV system has continued to decrease while the federal tax credit will drop from $26 \%$ to $22 \%$ in 2021 . At the same time solar panels are becoming more efficient along with shifts in manufacturing locations and processes that will influence the embodied environmental impacts. Additionally, the electric grid fuel mix continues to shift from coal towards natural gas and, to a lesser extent, renewables. All these factors will influence the benefits and costs associated with solar PV installations.

Significant effort and funding are required to maintain BIRDS. In addition, it has been determined there should be a shift to providing sustainability performance (economic and environmental) through separate software tools moving forward. As a consequence, the software tool BIRDS NEST, a collaboration with the Athena Sustainable Materials Institute (ASMI) and Department of Energy (DOE) National Renewable Energy Laboratory (NREL) that allows users to generate custom whole residential building LCIA results, is under development. BIRDS NEST combines the capabilities of Impact Estimator for Buildings with a more expansive set of residential building system options, allowing for whole building LCIA results estimates for any E+ whole building energy simulation developed in OpenStudio. A second software tool that is under development, the Economic Evaluation Engine (E3), provides an API that can be used for back-end calculations of LCCA. The E3 API provides a standardized format using the same ASTM Building Economic Standards implemented in BIRDS. By focusing on the underlying standards-based source data development and back-end calculations engines, NIST will be able to focus its resources on the greatest value add to society. Any user interface will be able to leverage the capabilities of BIRDS NEST and/or E3 to assist and accelerate their own development and analysis. 


\section{References}

[1] O'Rear E, Webb D, Kneifel J, O'Fallon C (2019) Gas vs electric: Heating system fuel source implications on low-energy single-family dwelling sustainability performance. Journal of Building Engineering 25:100779.

[2] EIA (2017b) U.S. households' heating equipment choices are diverse and vary by climate region (U.S. Energy Information Administration,). Available at https://www.eia.gov/todayinenergy/detail.php?id=30672.

[3] EIA (2017a) Annual Energy Outlook, with Projections to 2050. (U.S. Energy Information Administration, Washington, DC).

[4] DOE (2015) Building America Climate Region Map (U.S. Department of Energy (DOE),). Available at http://energy.gov/eere/buildings/building-america-climatespecific-guidance.

[5] Belsie L (2012) Cheapest way to heat your home? Four fuels compared. Available at https://www.csmonitor.com/Environment/2012/1207/Cheapest-way-to-heat-yourhome-Four-fuels-compared/Heating-oil-2-526.

[6] EIA (2015) Household heating costs are expected to be lower than previous two winters (U.S. Energy Information Administration,). Available at https://www.eia.gov/todayinenergy/detail.php?id=23232\#tabs_3.

[7] Jeong J, Kim CS, Lee J (2011) Household electricity and gas consumption for heating homes. Energy Policy 39(5):2679-2687.

[8] Gustavsson L, Karlsson $\AA$ (2002) A system perspective on the heating of detached houses. Energy policy 30(7):553-574.

[9] Cabrol L , Rowley P (2012) Towards low carbon homes-A simulation analysis of building-integrated air-source heat pump systems. Energy and Buildings 48:127-136.

[10] Kelly N , Cockroft J (2011) Analysis of retrofit air source heat pump performance: Results from detailed simulations and comparison to field trial data. Energy and Buildings 43(1):239-245.

[11] Dorer V, Weber A (2009) Energy and CO2 emissions performance assessment of residential micro-cogeneration systems with dynamic whole-building simulation programs. Energy Conversion and Management 50(3):648-657.

[12] Yang L, Zmeureanu R, Rivard H (2008) Comparison of environmental impacts of two residential heating systems. Building and Environment 43(6):1072-1081.

[13] Shah VP, Debella DC, Ries RJ (2008) Life cycle assessment of residential heating and cooling systems in four regions in the United States. Energy and buildings 40(4):503-513.

[14] Brenn J, Soltic P, Bach C (2010) Comparison of natural gas driven heat pumps and electrically driven heat pumps with conventional systems for building heating purposes. Energy and Buildings 42(6):904-908.

[15] Pitt D, Randolph J, Jean DS, Chang M (2012) Estimating potential community-wide energy and greenhouse gas emissions savings from residential energy retrofits. Energy and Environment Research 2(1):44.

[16] IEA (2017) Statistics: Key electricity trends 2016. (International Energy Agency (IEA), Paris, France).

[17] Martinopoulos G, Papakostas KT, Papadopoulos AM (2018) A comparative review of heating systems in EU countries, based on efficiency and fuel cost. Renewable and Sustainable Energy Reviews 90:687-699. 
[18] Martinopoulos G, Papakostas KT, Papadopoulos AM (2016) Comparative analysis of various heating systems for residential buildings in Mediterranean climate. Energy and Buildings 124:79-87.

[19] Abusoglu A, Sedeeq MS (2013) Comparative exergoenvironmental analysis and assessment of various residential heating systems. Energy and Buildings 62:268-277.

[20] Tsilingiridis G, Martinopoulos G, Kyriakis N (2004) Life cycle environmental impact of a thermosyphonic domestic solar hot water system in comparison with electrical and gas water heating. Renewable Energy 29(8):1277-1288.

[21] Hong B , Howarth RW (2016) Greenhouse gas emissions from domestic hot water: heat pumps compared to most commonly used systems. Energy Science \& Engineering 4(2):123-133.

[22] Greening B , Azapagic A (2014) Domestic solar thermal water heating: A sustainable option for the UK? Renewable Energy 63:23-36.

[23] Clark D (2012) Householders unlikely to recover solar heating installation costs for 30 years. Available at

https://www.theguardian.com/environment/2012/sep/21/householders-green-heatingcosts.

[24] Croxford B , Scott K (2006) Can PV or solar thermal systems be cost effective ways of reducing CO 2 emissions for residential buildings? (American Solar Energy Society (ASES)).

[25] Cassard H, Denholm P, Ong S (2011) Break-even cost for residential solar water heating in the United States: key drivers and sensitivities. (National Renewable Energy Laboratory (NREL), Golden, CO.).

[26] Rockenbaugh C, Dean J, Lovullo D, Lisell L, Barker G, Hanckock E, Norton P (2016) High Performance Flat Plate Solar Thermal Collector Evaluation. (National Renewable Energy Lab.(NREL), Golden, CO (United States)).

[27] Hang Y, Qu M, Zhao F (2012) Economic and environmental life cycle analysis of solar hot water systems in the United States. Energy and Buildings 45:181-188.

[28] Martinopoulos G (2014) Solar Heating Systems as a Viable Solution Towards Nearly Zero Energy Buildings. ASME 2014 8th International Conference on Energy Sustainability collocated with the ASME 2014 12th International Conference on Fuel Cell Science, Engineering and Technology (American Society of Mechanical Engineers), pp V002T010A012-V002T010A012.

[29] Martinopoulos G, Tsalikis G (2014) Active solar heating systems for energy efficient buildings in Greece: A technical economic and environmental evaluation. Energy and Buildings 68:130-137.

[30] Martinopoulos G (2018) Life Cycle Assessment of solar energy conversion systems in energetic retrofitted buildings. Journal of Building Engineering 20:256-263.

[31] Simons A , Firth SK (2011) Life-cycle assessment of a 100\% solar fraction thermal supply to a European apartment building using water-based sensible heat storage. Energy and Buildings 43(6):1231-1240.

[32] Kalogirou S (2009) Thermal performance, economic and environmental life cycle analysis of thermosiphon solar water heaters. Solar Energy 83(1):39-48.

[33] Diakoulaki D, Zervos A, Sarafidis J, Mirasgedis S (2001) Cost benefit analysis for solar water heating systems. Energy Conversion and Management 42(14):1727-1739. 
[34] Eguiarte O, Garrido-Marijuán A, de Agustín-Camacho P, del Portillo L, RomeroAmorrortu A (2020) Energy, Environmental and Economic Analysis of Air-to-Air Heat Pumps as an Alternative to Heating Electrification in Europe. Energies 13(15):3939.

[35] Zhao N, Zhang Y, Li B, Hao J, Chen D, Zhou Y, Dong R (2019) Natural gas and electricity: Two perspective technologies of substituting coal - burning stoves for rural heating and cooking in Hebei Province of China. Energy Science \& Engineering 7(1):120-131.

[36] Zhang H, Zhou L, Huang X, Zhang X (2019) Decarbonizing a large City's heating system using heat pumps: A case study of Beijing. Energy 186:115820.

[37] Lippiatt B, Kneifel J, Lavappa P, Suh S, Greig A (2013) Building Industry Reporting and Design for Sustainability (BIRDS) Technical Manual and User Guide. NIST Technical Note 1814.

[38] Bare J (2011) TRACI 2.0: the tool for the reduction and assessment of chemical and other environmental impacts 2.0. Clean Technologies and Environmental Policy 13(5):687-696.

[39] Hendron R, Engebrecht C (2010) Building America House Simulation Protocols (National Renewable Energy Laboratory), US Department of Energy (Energy Efficiency and Renewable Energy).

[40] ASHRAE (2010) American Society of Heating, Refrigerating and Air-Conditioning Engineers Standard 62.2-2010. Available at www.ashrae.org.

[41] DOE (2015a) EnergyPlus Simulation SoftwareVersion 8.3.0 (U.S. Department of Energy, Building Technologies Program (BTP),

[42] Zhang Y, Korolija I (2015) jEPlus v1.5.1 (Building Technologies Program, Version 8.0.0

[43] Weather Analytics (2014) TMY Meteorological Year 3 (TMY) Formatted Weather Data File. ed Database A-GW (Athenium Analytics (formerly Weather Analytics), https://www.athenium.com/).

[44] Kneifel J, Webb D, O’Rear E (2016) Energy and Economic Implications of Solar Photovoltaic Performance Degradation. Special Publication (NIST SP)-1203.

[45] Suh S , Lippiatt BC (2012) Framework for hybrid life cycle inventory databases: a case study on the Building for Environmental and Economic Sustainability (BEES) database. The International Journal of Life Cycle Assessment 17(5):604-612.

[46] Bagley S, Crawford RH (2015) Using life cycle assessment to reduce the energy use and global warming impacts of a detached house in Melbourne, Australia. Living and Learning: Research for a Better Built Environment: Proceeding of the 49th

International Conference of the Architectural Science Association, pp 143-152.

[47] Crawford R, Bartak E, Stephan A, Jensen C (2016) Evaluating the life cycle energy benefits of energy efficiency regulations for buildings. Renewable and Sustainable Energy Reviews 63:435-451.

[48] Stephan A, Crawford RH (2016) The relationship between house size and life cycle energy demand: Implications for energy efficiency regulations for buildings. Energy 116:1158-1171.

[49] Stephan A, Jensen CA, Crawford RH (2017) Improving the life cycle energy performance of apartment units through façade design. 
[50] Crawford RH, Stephan A (2013) The significance of embodied energy in certified passive houses. Proceedings of World Academy of Science, Engineering and Technology, (World Academy of Science, Engineering and Technology (WASET)), $\mathrm{p}$ 453.

[51] Kneifel J, O'Rear E, Webb D, O'Fallon C (2018) An exploration of the relationship between improvements in energy efficiency and life-cycle energy and carbon emissions using the BIRDS low-energy residential database. Energy and Buildings 160(Supplement C):19-33. https://doi.org/https://doi.org/10.1016/j.enbuild.2017.11.030

[52] Skone TJ (2019) Grid Mix Explorer Version 4. (United States).

[53] Turner MZ, Alexander J, Woods, Mark (2019) Cost and Performance Baseline for Fossil Energy Plants Volume 1: Bituminous Coal and Natural Gas to Electricity, Revision 4: Final Presentation. DOE/NETL 2020/2612.

[54] Littlefield J, Roman-White S, Augustine D, Pegallapati A, Zaimes GG, Rai S, Cooney G, Skone TJ (2019) Life cycle analysis of natural gas extraction and power generation. (NETL).

[55] NETL (2015) NETL Lifecycle Inventory Data - Unit Process: "\&D3\&”. (U.S. Department of Energy, National Energy Technology Laboratory. Last Updated 2015 (version 01)). Available at www.netl.doe.gov/LCA (http://www.netl.doe.gov/LCA).

[56] Fuller S, Petersen S (1996) Life-Cycle Costing Manual for the Federal Energy Management Program, 1995 Edition. NIST handbook 135.

[57] ASTM (2012) Standard Guide for Selecting Economic Methods for Evaluating Investments in Buildings and Building Systems, ASTM Designation E1185-12. (West Conshohocken, PA).

[58] RS Means (2017). Available at https://www.rsmeans.com.

[59] Faithful and Gould (2012) Residential Energy Efficiency Measures: Prototype Estimate and Cost Data Revision 6.0. (National Renewable Energy Laboratory).

[60] Kneifel J , O'Rear E (2016b) Net-Zero Energy Residential Building Component Cost Estimates and Comparisons. NIST Special Publication 1207.

[61] Webb DK, Joshua; O'Fallon, Cheyney (2020) Developing Cost Functions for Estimating Solar Photovoltaic System Installed and Life Cycle Costs Using Historical Quote Data. NIST Technical Note 2113.

[62] Census (2011) American Housing Survey (AHS) for the United States, Series H-150, Complete Set of Tables and Standard Errors (Department of Commerce, U.S. Census Bureau). Available at http://www.census.gov/programs-surveys/ahs/.

[63] National Association of Home Builders (NAHB) Research Center (2007) Study of Life Expectancy of Home Components. (National Association of Home Builders).

[64] ENERGY STAR (2011) Certified Products - Lighting. Available at https://www.energystar.gov/products/lighting_fans.

[65] PEPCO (2018) Maryland Residential Service Scheduler R. Available at http://www.pepco.com/MyAccount/MyBillUsage/Documents/Updated\%20010418\%20R.pdf.

[66] EIA (2017d) Natural Gas Prices (U.S. Energy Information Administration (EIA),). Available at https://www.eia.gov/dnav/ng/ng_pri_sum_a_EPG0_PRS_DMcf_a.htm. 
[67] Lavappa P, Kneifel J, O'Rear E (2017) Energy Price Indices and Discount Factors for Life-Cycle Cost Analysis - 2017, Annual Supplement to NIST Handbook 135, US Department of Commerce (National Institute of Standards and Technology).

[68] ASTM (2012) ASTM Standards on Building Economics: 7th Edition (ASTM International, West Conshohocken, PA).

[69] Congress (2015) H.R. 2029 - Consolidated Appropriations Act, 2016.

[70] ASHRAE (2010) Thermal Environmental Conditions for Human Occupancy, ASHRAE Standard 55-2010. (American Society of Heating, Refrigerating and AirConditioning Engineers, Atlanta, GA).

[71] Kneifel J, Lavappa P, O'Rear E, Greig AL, Suh S (2017) BIRDS v3.1 Low-Energy Residential Database Technical Manual. NIST Technical Note 1956.

\section{Appendix A}

Table A-1. Constructions - Roof, Ceiling, Wall and Foundation

\begin{tabular}{|c|c|c|c|c|c|c|}
\hline \multicolumn{2}{|c|}{ Wall Constructions $^{14}$} & Option 1 & Option 2 & Option 3 & Option 4 & Option $5^{\circ}$ \\
\hline \multirow[t]{2}{*}{ Exterior Wall } & Framing & Typical† & Typical & Advanced $+\dagger$ & Advanced & Advanced \\
\hline & Insulation & $\mathrm{R}_{\mathrm{SI}}-2.3$ & $\mathrm{R}_{\mathrm{SI}}-2.3+0.9^{*}$ & $\mathrm{R}_{\mathrm{SI}}-3.5$ & $\mathrm{R}_{\mathrm{SI}}-3.5+2.1^{*}$ & $\mathrm{R}_{\mathrm{SI}}-3.5+4.2^{*}$ \\
\hline \multicolumn{2}{|c|}{ Foundation Constructions } & Option 1 & Option 2 & Option 3 & Option 4• & \\
\hline Basement & Wall; Slab & $\mathrm{R}_{\mathrm{SI}^{-}}-1.41 ; \mathrm{R}_{\mathrm{SI}^{-}} 0$ & $\mathrm{R}_{\mathrm{SI}^{-}}-1.76 ; \mathrm{R}_{\mathrm{SI}^{-}} 0$ & $\mathrm{R}_{\mathrm{SI}^{-}}-3.9 ; \mathrm{R}_{\mathrm{SI}^{-}} 0$ & $\mathrm{R}_{\mathrm{SI}^{-}}-3.9 ; \mathrm{R}_{\mathrm{SI}^{-}}-1.8$ & \\
\hline \multicolumn{2}{|c|}{ Roof/Ceiling Constructions } & Option 1 & Option 2 & Option 3 & Option 4 & Option 5• \\
\hline \multirow[t]{2}{*}{ Roof/Ceiling } & Roof** & $\mathrm{R}_{\mathrm{SI}^{-}}-0$ & $\mathrm{R}_{\mathrm{SI}^{-}}-0$ & $\mathrm{R}_{\mathrm{SI}^{-}}-7.92+0.7$ & $\mathrm{R}_{\mathrm{SI}^{-}}-7.92+2.64$ & $\mathrm{R}_{\mathrm{SI}^{-}}-7.92+5.28$ \\
\hline & Ceiling*** & $\mathrm{R}_{\mathrm{SI}^{-}}-6.69$ & $\mathrm{R}_{\mathrm{SI}}-8.63$ & $\mathrm{R}_{\mathrm{SI}^{-}} 0$ & $\mathrm{R}_{\mathrm{SI}^{-}} 0$ & $\mathrm{R}_{\mathrm{SI}}-0$ \\
\hline
\end{tabular}

Table A-2. Window Design Options

\begin{tabular}{ccccccc}
\hline Parameter $^{15}$ & Units & Option 1 & Option 2 & Option 3 & Option 4 & Option 5 \\
\hline U-Factor; SHGC & $\mathrm{W} / \mathrm{m}^{2}-\mathrm{K} ;$ Fraction & $2.57 ; 0.60$ & $2.28 ; 0.60$ & $2.00 ; 0.60$ & $2.00 ; 0.40$ & $1.14 ; 0.25$ \\
\hline
\end{tabular}

\footnotetext{
14 The R-values (R) in Table A-1 refer to the capacity of an insulating material to resist heat flow. A higher R-value implies a greater insulating power. The $\mathrm{R}_{\mathrm{SI}}$ values are the derived SI units.

${ }^{15} U$-factor refers to the heat loss of a window assembly. A lower U-factor implies a greater resistance by the window to heat flow. The solar heat gain coefficient $(S H G C)$, a fractional number between 0 and 1 , refers to the fractional amount of incident solar radiation admitted through a window.
} 
Table A-3. Design Options for Alternative Air Leakage Rates

\begin{tabular}{cccc} 
Design Option & \multicolumn{3}{c}{ Assumed Effective Leakage Area $\left(\mathbf{c m}^{2}\right)$} \\
& ACH50 $^{16}$ & $\mathbf{1}^{\text {st }}$ Floor & 2 $^{\text {nd }}$ Floor \\
\hline Option 1 (2003 \& 2006 / 2009 IECC) & No Maximum / 7.00 & 1473.3 & 1343.3 \\
\hline Option 2 (2012/2015 IECC) & 3.00 & 403.6 & 368.1 \\
\hline Option 3 (NZERTF) & 0.63 & 132.6 & 120.9 \\
\hline
\end{tabular}

Table A-4. Fraction of High Efficiency Fixtures by Requirement

\begin{tabular}{ccccc} 
& Option 1 (2003/2006) & Option 2 (2009) & Option 3 (2012/2015) & Option 4 (NZERTF) \\
\hline Fraction & $34 \%$ & $50 \%$ & $75 \%$ & $100 \%$ \\
\hline
\end{tabular}

Table A-5. Heating and Cooling Equipment Design Options

\begin{tabular}{cc} 
Design Option & System Components ${ }^{17}$ \\
Option 1 & Air-to-air heat pump (SEER 13/HSPF 7.7); Min. Outdoor Air $\left(0.04 \mathrm{~m}^{3} / \mathrm{s}\right)$ \\
\hline Option 2 (NZERTF) & Air-to-air heat pump (SEER 15.8/HSPF 9.05); Separate HRV system $\left(0.04 \mathrm{~m}^{3} / \mathrm{s}\right)$ \\
\hline Option 3 & Gas-electric split A/C system (SEER 13/80\% AFUE); Min. Outdoor Air $\left(0.04 \mathrm{~m}^{3} / \mathrm{s}\right)$ \\
\hline Option 4 & Gas-electric split A/C system (SEER 16/96\% AFUE); Separate HRV system $\left(0.04 \mathrm{~m}^{3} / \mathrm{s}\right)$ \\
\hline
\end{tabular}

Table A-6. Domestic Hot Water System Design Options

\begin{tabular}{cr} 
Design Option & \multicolumn{1}{c}{ System Components } \\
Option 1 & 189 L electric water heater $(\mathrm{EF}=0.95) ;$ No Auxiliary \\
\hline Option 2 & 189 L HPWH $(\mathrm{COP} 2.36) ;$ No Auxiliary \\
\cline { 2 - 2 } Option 3 & 189 L electric water heater $(\mathrm{EF}=0.95) ; 2$ panel, 302.8 L solar thermal storage tank \\
\hline Option 4 (NZERTF) & 189 L HPWH $(\mathrm{COP} 2.36) ; 2$ panel, 302.8 L solar thermal storage tank \\
\hline Option 5 & 189 L gas water heater $(\mathrm{EF}=0.78) ;$ No Auxiliary \\
\hline Option 6 & 189 L gas water heater $(\mathrm{EF}=0.90) ;$ No Auxiliary \\
\hline Option 7 & 189 L gas water heater $(\mathrm{EF}=0.78) ; 2$ panel, 302.8 L solar thermal storage tank \\
\hline Option 8 & 189 L gas water heater $(\mathrm{EF}=0.90) ; 2$ panel, 302.8 L solar thermal storage tank \\
\hline
\end{tabular}

Table A-7. Solar PV System Options

\begin{tabular}{ccccccc}
\hline Design Option & Option 1 & Option 2 & Option 3 & Option 4 & Option 5 & Option 6 \\
\hline System Size (kW) & 0.0 & 2.5 & 5.1 & 7.6 & 10.2 & 12.7 \\
\hline
\end{tabular}

\footnotetext{
${ }^{16} \mathrm{ACH}_{50}$ - Air Changes per Hour at 50 Pascals

${ }^{17}$ SEER is the rated cooling efficiency. HSPF is a measure of heating efficiency for air-source heat pumps. Annual fuel utilization efficiency (AFUE) factor indicates how efficiently a furnace utilizes it fuel.

${ }^{18}$ Energy efficiency of a water heater is indicated by EF based on the amount of hot water produced per unit of fuel consumed over a typical day. $\mathrm{COP}$ is the ratio of useful heating/cooling to work required, characterizing heat pump/AC unit performance.
} 
Table A-8. Normalization References (Annual U.S. Contributions) and EIS Weights

\begin{tabular}{|ccccc|}
\hline Impact Category & $\begin{array}{c}\text { Normalization } \\
\text { reference }\end{array}$ & Units & $\begin{array}{c}\text { EPA Science } \\
\text { Advisory } \\
\text { Board }\end{array}$ & $\begin{array}{c}\text { BEES } \\
\text { Stakeholder } \\
\text { Panel }\end{array}$ \\
\hline Global Warming & $7.16 \mathrm{E}+12$ & $\mathrm{~kg} \mathrm{CO}_{2}$ eq. & 18 & 29.9 \\
\hline Primary Energy Consumption & $3.52 \mathrm{E}+13$ & $\mathrm{kWh}$ & 7 & 10.3 \\
\hline HH - Criteria Air & $2.24 \mathrm{E}+10$ & $\mathrm{~kg} \mathrm{PM10} \mathrm{eq.}$ & 7 & 9.3 \\
\hline $\mathrm{HH}-$ Cancer (Carcinogenic) & $1.05 \mathrm{E}+04$ & $\mathrm{CTUh}$ & 8 & 8.2 \\
\hline Water Consumption & $1.69 \mathrm{E}+14$ & $\mathrm{~L}$ & 3 & 8.2 \\
\hline Ecological Toxicity & $3.82 \mathrm{E}+13$ & $\mathrm{CTUe}$ & 12 & 7.2 \\
\hline Eutrophication & $1.01 \mathrm{E}+10$ & $\mathrm{~kg} \mathrm{~N}$ eq. & 5 & 6.2 \\
\hline Land Use & $7.32 \mathrm{E}+08$ & hectare & 18 & 6.2 \\
\hline HH - Non-cancer (Non-Carcinogenic) & $5.03 \mathrm{E}+05$ & $\mathrm{CTUh}$ & 5 & 5.2 \\
\hline Smog Formation & $4.64 \mathrm{E}+11$ & $\mathrm{~kg} \mathrm{O}$ eq. & 7 & 4.1 \\
\hline Acidification & $1.66 \mathrm{E}+12$ & mol H+ eq. & 5 & 3.1 \\
\hline Ozone Depletion & $5.10 \mathrm{E}+07$ & kg CFC-11-eq. & 5 & 2.1 \\
\hline
\end{tabular}

